\title{
Új irányok a khmer településtörténeti hálózatok kutatásában (Koh Ker, Kambodzsa)
}

A Khmer kulturális örökség számbavétele, feldolgozása, restaurálása, állagmegóvása komoly nemzetközi együttmüködés eredményének köszönhetö. $\mathrm{Az}$, hogy évente turisták milliói látogathatják az Angkor régió lenyügöző épületeit, számos helyi és külföldi kutató, illetve kutatócsapat szisztematikus munkáját dicséri, az pedig külön öröm, hogy ebbe a különleges misszióba a francia, japán, ausztrál, kínai, indiai szakemberek után több magyar csapat is bekapcsolódhatott.

Kutatásunk színhelye, Koh Ker, a sokak számára ismert Angkortól mintegy 100 km-re található, az egykori északi-északkeleti regionális központok - Vat Phou (ma Laosz területén) és Preah Vihear (Kambodzsa) - irányába haladó kereskedelmi utak csomópontjában.

A $80 \mathrm{~km}^{2}$ nagyságú, védett erdőt és számos 10-13. század között épült khmer templomot, kisebb szentélyt magában foglaló területnek az alig néhány száz lelket számláló falu, Koh Ker kölcsönzi jelenleg ismert nevét. Történetével kapcsolatban ugyanakkor általánosan elfogadott az a vélekedés, hogy 928 és 944 között itt, a „Chok Gargyar”, azaz a „koki fákligetének” hegyén állt a Khmer Birodalom történeti forrásokban „Lingapuraként” említett fővárosa. A feltehetően helyi kötődésü IV. Jayavarman király ugyanis az Angkor régióból ide helyezte át a birodalom központját, amely csak fia, II. Harśavarman uralkodását (941-944) követően került vissza a korábbi helyszínre. A templomok, szentélyek nagy száma és a felszínen található intenzív régészeti leletanyag, illetve a fennmaradt szanszkrit, ókhmer feliratok egy része arra utal, hogy Koh Ker jelentősége a 10. század közepe után sem halványult el, a rövid, reprezentatív időszak után regionális központi szerepe mindvégig fennmaradt (1. kép).

A történeti településrendszer reprezentatív belső magja mintegy $9 \mathrm{~km}^{2}$-en terül el. Központi, domináns létesítménye a $1200 \times 600$ méteres, téglalap alakú víztározó, a Rahal, s az ennek a keleti, illetve nyugati partját követő 


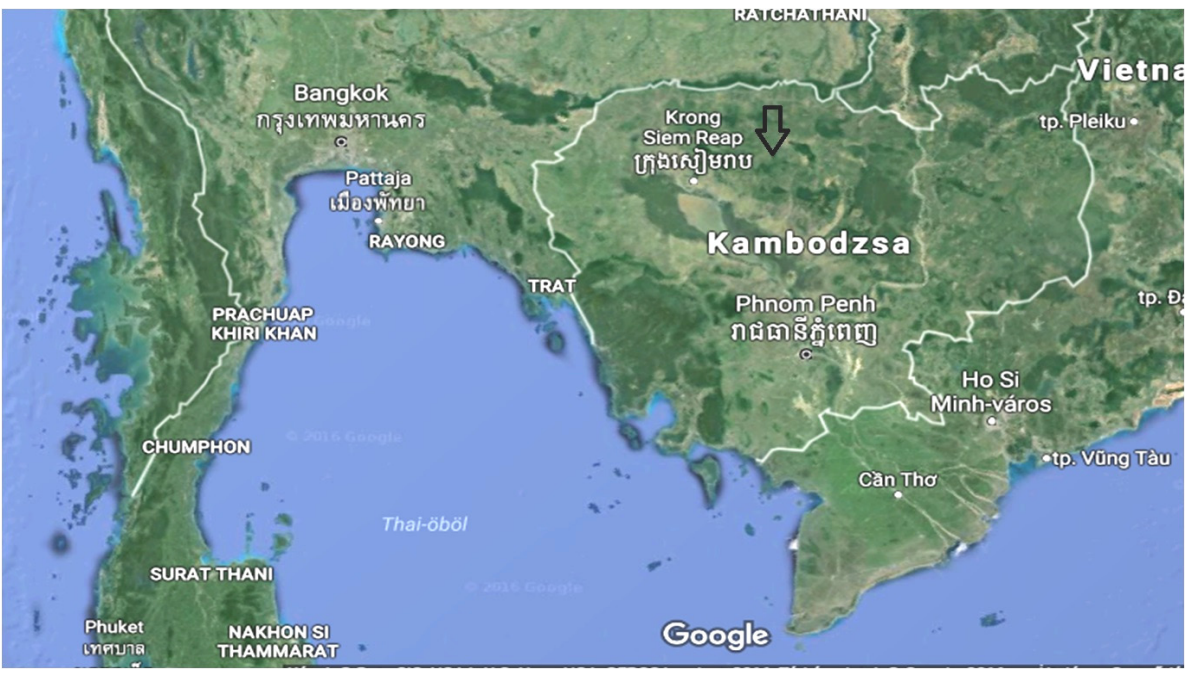

1. kép Koh Ker Kambodzsa északi részén, Preah Vihear tartományban (forrás: Google Maps)

magaslatokon több reprezentatív épületcsoportot találunk. A víztározótól északnyugatra helyezkedik el a központi szentély. A Prasath Thom és a hozzá csatlakozó ún. Prasat Krahom együttesét és egyben az egész „kompozíciót" nyugatról egy hétlépcsős, 36 méter magas, Sivának dedikált piramis - Koh Ker talán legismertebb épülete - zárja le (2-3. kép).

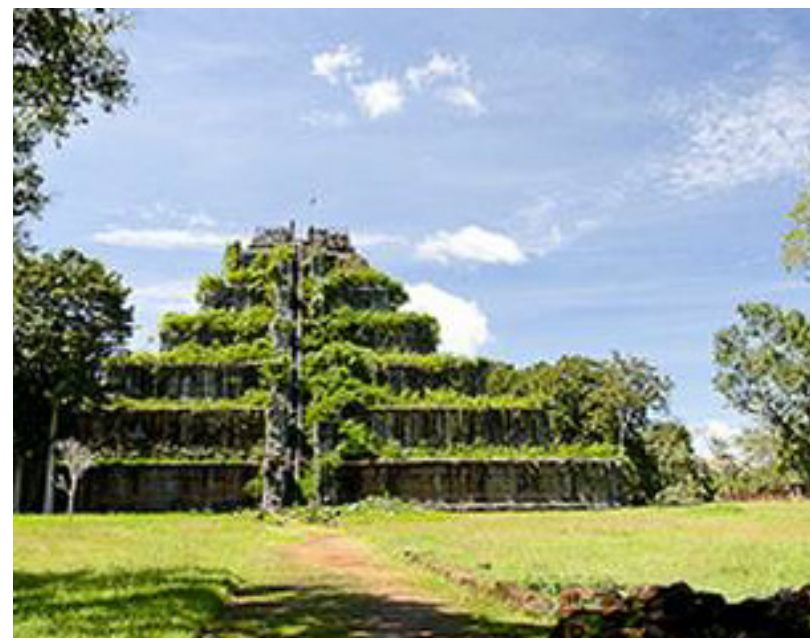

2. kép Piramis, Koh Ker (a szerzö felvétele) 


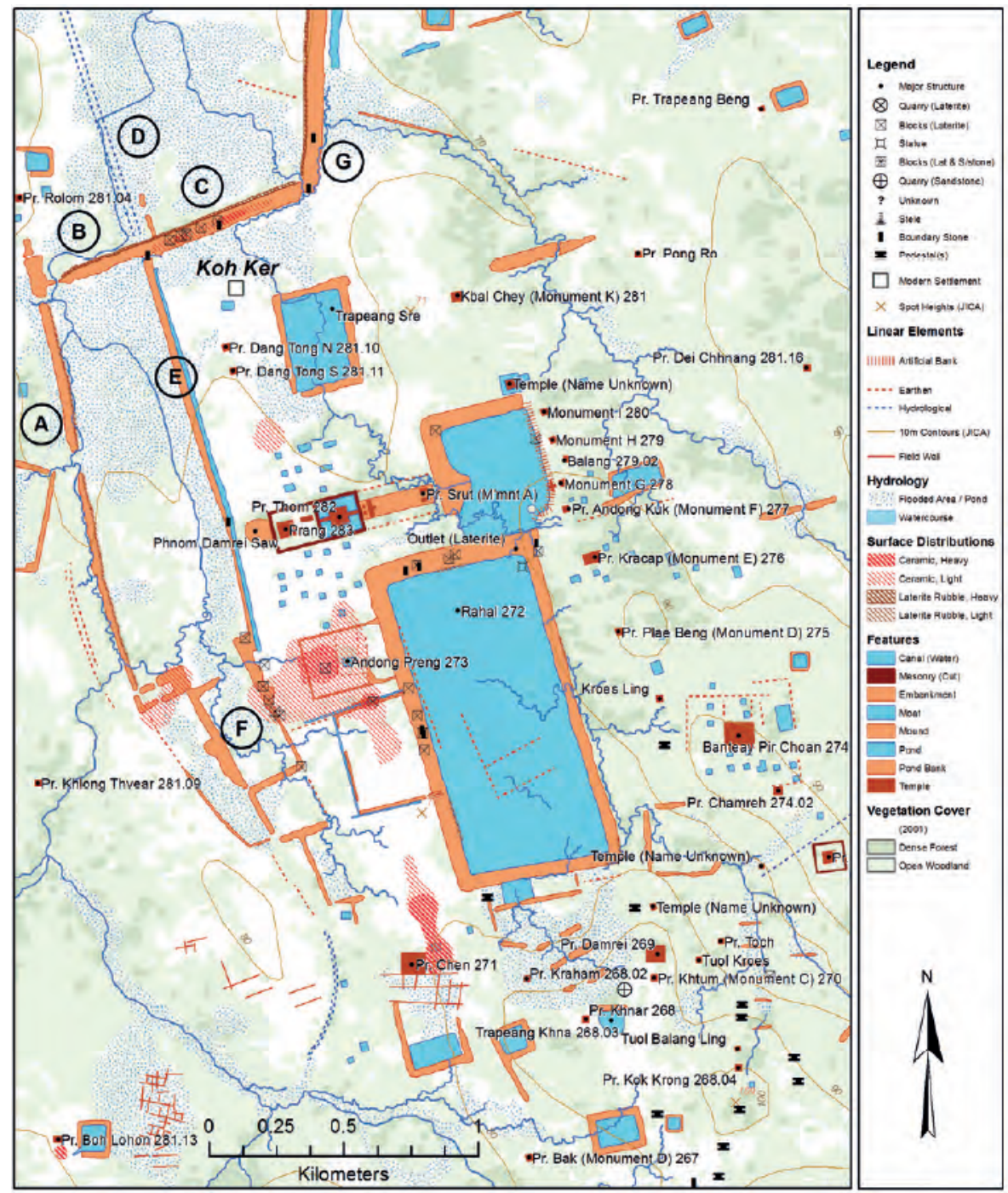

3. kép A terület belsö, reprezentatív magja Damien Evans felmérésén (Evans 2013: 144)

Az izgalmas és egyedi történeti háttér önmagában is nagyon izgalmassá teszi a természeti értékként is védett, a környező dzsungellel különös szimbiózisban élő „romvárost”. Ugyanakkor az óriási területen szétszórt önálló épületcsoportok kutatása és megóvása óriási szakmai kihívás. A teljes védett zónán belül ugyanis közel 130 régészeti lelőhely, köztük 54 ma is álló templom ismert. Ezért a hatalmas, régészeti lelőhelyekben és műemlékekben gaz- 
dag terület kapcsán a valódi munka megkezdése elött az embernek óhatatlanul szembesülnie kell néhány módszertani kérdéssel. Ezek közül kétségtelenül a legfontosabb, hogy a legtöbb kambodzsai régészeti lelőhely, így Koh Ker - minden egyedisége ellenére - sem más, mint egy „régészeti lelöhely". Ezért itt is a régészeti feltárásokra és dokumentációra vonatkozó általános gyakorlatot kell alkalmaznunk a dokumentáció, feltárási stratégia, feldolgozás, közzététel folyamatában. Fontos ugyanakkor belátnunk, hogy egy ekkora terület teljes egészében gyakorlatilag feltárhatatlan. Erre még több emberöltő sem lenne elég. A terület részleges bejárása során szerzett tapasztalatok alapján egyértelmű volt, hogy a kutatási stratégiát egy kiválasztott helyszín teljes körủ feltárásának kell szentelnünk. A több helyszínen folyó kisebb felületü kutatások szétszórnák az erőforrásainkat, egy helyszínen, koncentrált munkavégzéssel viszont olyan mintaprojekteket (kisebb szisztematikus feltárásokat) hozhatunk létre, amelyek segíthetnek értelmezni az egész területre vonatkozó alapvizsgálatok, a 19. század legvégén kezdődött és jelenleg is folyó történeti, művészettörténeti, topográfiai felmérések, illetve a jövőben várhatóan egyre több régészeti kutatás eredményeit (4. kép). ${ }^{1}$

A konkrét régészeti feltárásokkal kapcsolatos másik el nem hanyagolható probléma, hogy a régészeti lelöhelyek többsége egyben épített környezet is, amelynek feltárására speciális szabályok vonatkoznak, tehát a régészeti feltárással párhuzamosan müemléki kutatási, felmérési feladataink is keletkeznek. Sőt az erdő által erősen igénybe vett területen a feltárással párhuzamosan az épületek müszaki állapota is folyamatos felügyeletet kíván (5. kép).

Fontos a legelején belátni, hogy egy-egy épületcsoport feltárása egy olyan folyamat kezdete, amelynek a végén az adott terület teljesen átalakul, a cél pedig egyértelmüen az Angkor régióban ismert helyreállított műemlékekhez hasonló, turisták által is látogatható, minden elemében élvezhető „végeredmény" létrehozása.

A fentieket figyelembe véve a kutatás megkezdése előtt igyekeztünk olyan területet kiválasztani, amely egyszerre ígéretes történeti, illetve múvészettörténeti szempontból, és müszaki, statikai állapota kevésbé veszélyezteti a környezetében folyó ásatást.

Evans 2013: 91-95. 

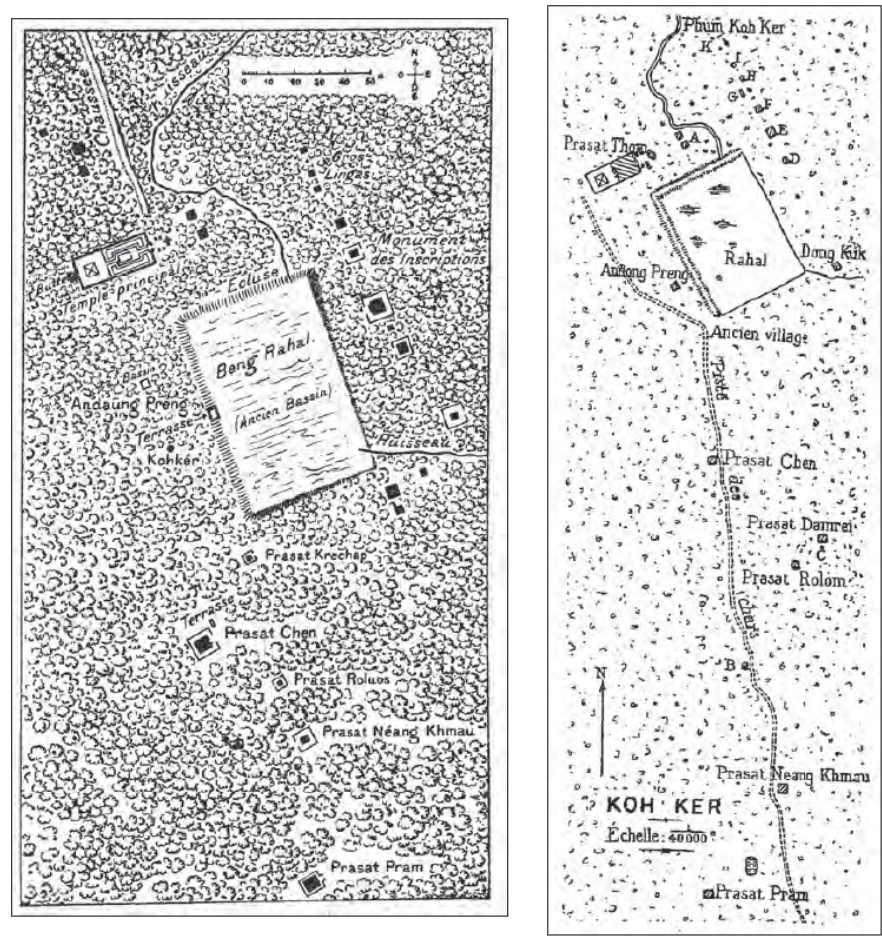

4. kép Étienne Aymonier (publikálva 1900-ban, balra) és Lunet de Lajonquière (publikálva 1902-ben, jobbra) felmérése Koh Kerröl (Evans 2013: 137. fig. 2.)

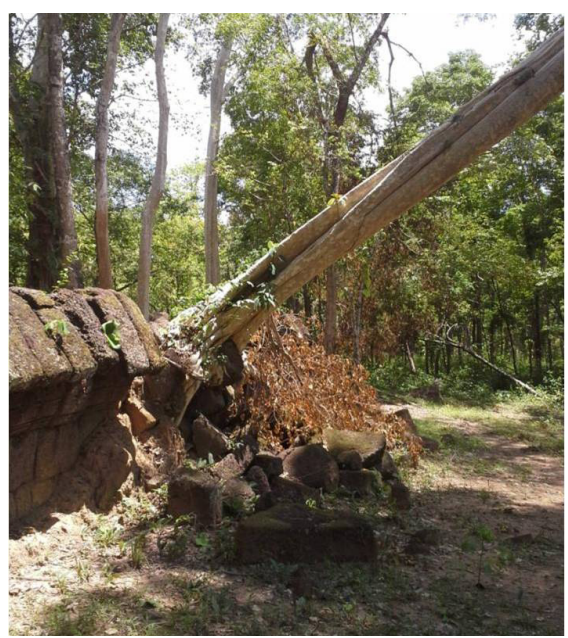

5. kép Kidölt trópusi fa által rongált falszakasz, Koh Ker (a szerzö felvétele) 
Így esett a választás a Koh Kerből ismert mindösszesen 38 közül 16 szanszkrit, illetve ókhmer feliratos kőtáblát rejtő, az öt belső téglaszentélyével is egyedinek mondható Prasat Krachapra. A Rahal északkeleti sarkától mintegy 200 méterre fekvő szentélyegyüttes tájolása a központi szentélyét (Prasat Thom) követi, de vele ellentétben nyugat felé néz. A tájolásából adódóan feltehetően Visnunak ajánlott templom keleti és nyugati galériapárjaiból és szentélyeiből ismert feliratos emlékek az építéstörténetröl ugyan keveset árulnak el, egy töredék alapján azonban első periódusa bizonyosan 928 elöttre keltezhetö (6. kép). ${ }^{2}$

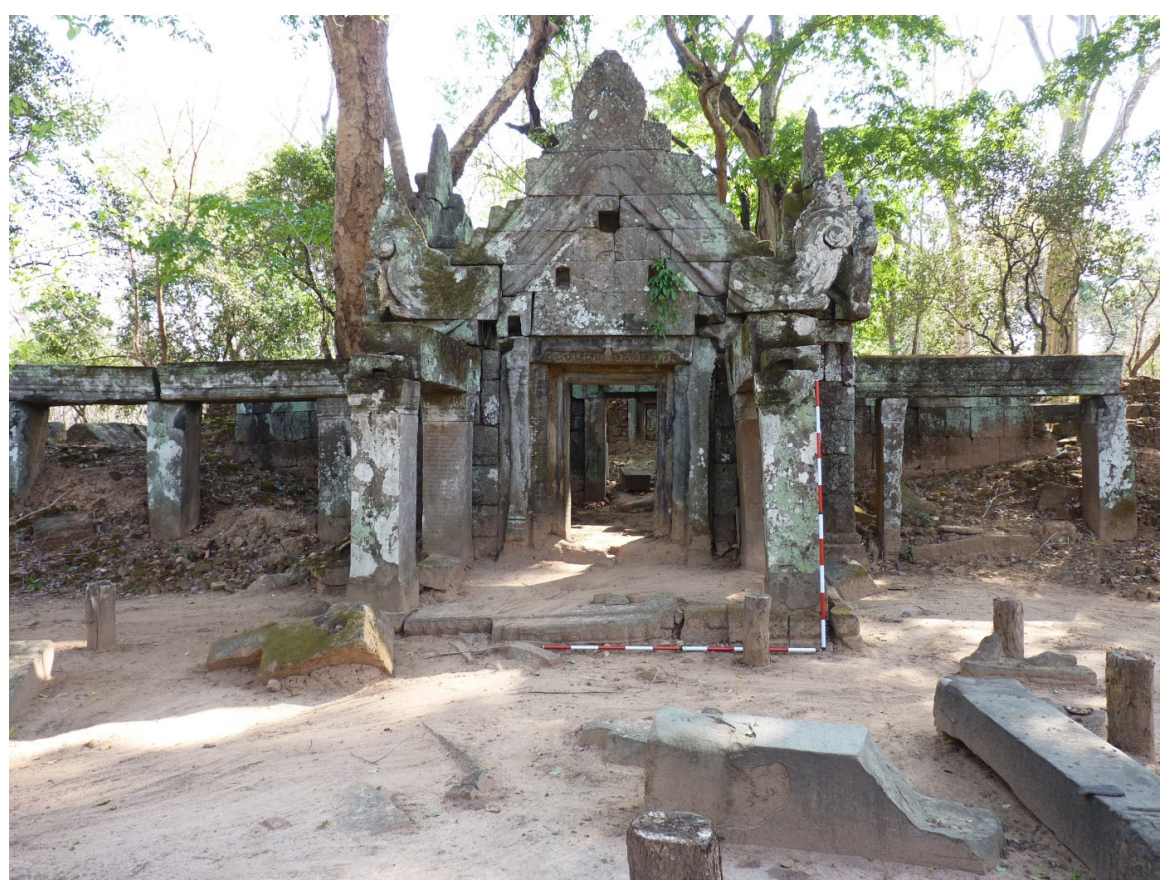

6. kép A Prasat Krachap nyugati homlokzata (a szerzö felvétele)

2 Jacques 2011: 3-4. 


\section{Régészeti kutatások a Prasat Krachap területén és közvetlen környezetében ${ }^{3}$}

A feltárást kellő alapossággal igyekeztünk előkészíteni. Így annak megkezdése előtt a felszínen felismerhető leleteket is vizsgáltuk. A terepbejárás során, az épületcsoport területén, illetve annak közvetlen környezetében mintegy $12000 \mathrm{~m}^{2}$ felületet kutatunk át, és a felszínen gyüjtött régészeti leletanyag előkerülési helyét a $10 \times 10$ méteres négyzethálón belül rögzítettük

A leletgyüjtést a környező területek mellett természetesen az épületcsoportra is kiterjesztettük. Az épület (föként a keleti és nyugati galériasor), illetve a bejáratok környezetében nagy mennyiségben kerültek elő az egykori tető cserépfedésének mázatlan töredékei. A kincskeresők által bolygatott omladékokban szinte eredménytelen volt a kutatás. Ennek ellenére a déli oldalon a szentélyeket körülvevő kerítőfalon keresztül kidobott téglatörmelékből nagy mennyiségü, reprezentatív kerámiaanyag került elö.

Röviden összefoglalva a terepbejárás eredményeit, elmondhatjuk, hogy a felszíni gyüjtés során előkerült leletek a Prasat Krachap müködésével és a környezetében élők mindennapi életével kapcsolatos információk gazdag forrásának mutatkoztak. A töredékek egy-egy területen belüli sürüsödése arra utalt, hogy a Prasat közvetlen környezete is lakott lehetett. A leletanyag elözetes vizsgálata pedig a terület 10-11. századi, illetve 11-13. század közötti intenzív életére utalt (7. kép). ${ }^{4}$

\section{Szondázó régészeti kutatás}

A 2011-ben kezdődő szondázó kutatás során elsősorban az épület és közvetlen környezetének kapcsolatát, a nem tisztázott épületrészleteket, illetve a kronológiai viszonyokat akartuk tisztázni. ${ }^{5}$

3 Belényesy - Ea 2011, Belényesy 2013.

4 Tanulságos, hogy a felszíni leletgyüjtés során ugyan fémkereső műszert is használtunk, ennek során azonban csak újkori fémtárgyak, modern hulladék került elő. Mivel a felszínt az aknamentesítés során alaposan átkutatták, a müszeres leletfelderítésnek jelentősége majd csak később, a feltárások folyamán lehet.

5 A dokumentáció alapja a rétegviszonyok és az előkerült leletanyag kapcsolatának leírására kialakított egyedi stratigráfiai rendszer volt. A feltárt szelvényekről és jelenségekről felszín- és metszetrajzok, fotódokumentáció és szisztematikus, adatlapok 


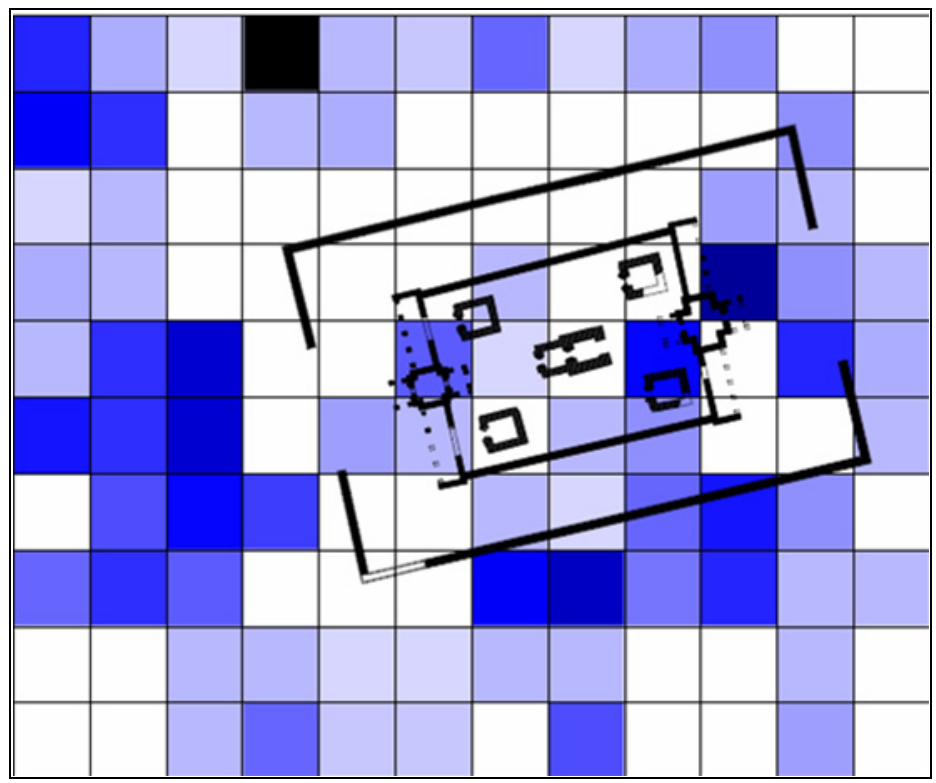

7. kép A leletgyüjtés zónái és a leletsürüség a terepbejárási térképen

\section{A nyugati pavilon}

Az egykor az épületcsoport nyugati kapuja előtt álló épület alapfalai és az alapozás nagyméretű tömbje már a terepbejárás során szembeötlő volt. Annak ellenére, hogy az épület felételezett kő részleteit nagy mennyiségü újkori szemét takarta, az egykori alap, illetve felmenő falak laterite ${ }^{6}$ tömbjei árulkodóak voltak. A modern szemétrétegek eltávolítása után pedig gyakorlatilag tisztán kivehetővé váltak a fontosabb alaprajzi részletek is, így különösen a délkeleti és délnyugati sarkok, illetve a nyugati támfal és az egykori lábazati szint. Az épület kelet-nyugati tengelyében azonosított lépcsőnek csak kisebb részleteit sikerült feltárnunk, de a szondák tanúsága szerint az épület délnyugati sarka és az épület nyugati falának részletei viszonylag épségben maradtak meg a föld alatt (8-9. kép).

segítségével történő leírás készült, amit a feltárás menetének naplószerü dokumentálásával egészítettünk ki.

6 A laterite a magmás kőzetek vasban gazdag, ezért téglavörös színű, a trópusokra jellemző mállásterméke, a homokkő mellett a leggyakrabban használt, építőanyag. 


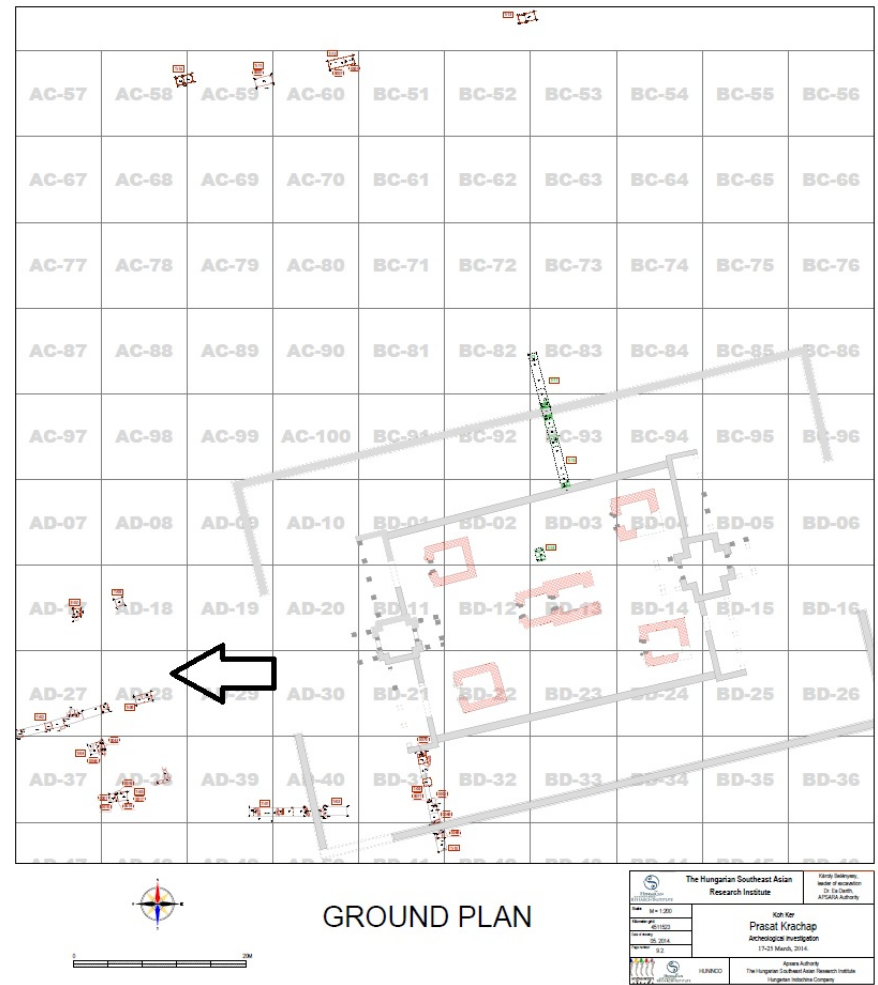

8. kép Szondák a nyugati pavilon területén (összesitö feltárási alaprajz: 2011-2015)

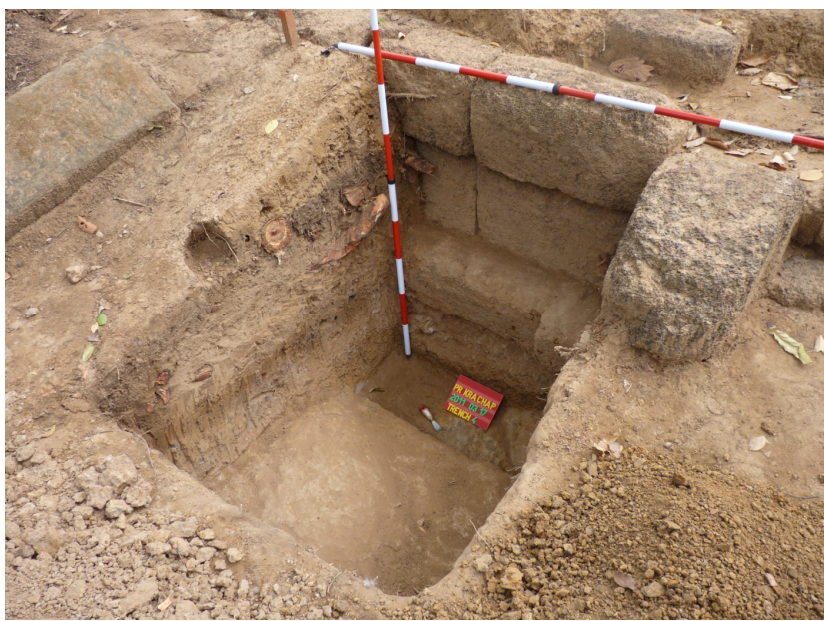

9. kép A pavilonépület nyugati falszakasza (a szerző felvétele) 
A szondákban több helyen is sikerült megfigyelnünk az alapozásokhoz kapcsolódó építési szinteket, illetve az épület egyes felmenő szakaszait is.

Az épület feltételezett, kereszt alakú alaprajza a bejárat, illetve a belső épületcsoport fö tengelyéhez igazodik. Funkcióját tekintve azonban egyelőre csak feltételezésekbe bocsátkozhatunk. ${ }^{7}$

Talán a legizgalmasabb kérdés az épületnek az ismert épületcsoporthoz való csatlakozása. A jelenlegi bejárat előtt ugyanis a kerítőfal megszakad, itt a felszínen épület nyoma nem látszik, ugyanakkor a Prasat Krachap 1930-as években készült, Henri Parmantier-féle felmérésén (10. kép) a kerítőfal nyugati és keleti oldalán is egy-egy Gopura szerepel!

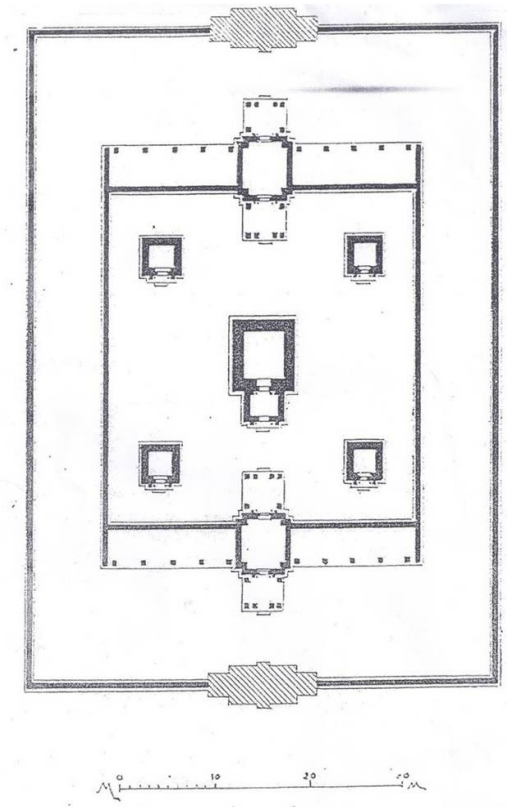

10. kép A Prasat Krachap felmérése

(Parmentier 1939: 58)

7 Akárcsak az épület funkciójával kapcsolatban, az elnevezésben is van némi bizonytalanság. Olivier Cunin inkább a bejárati pavilon megnevezést támogatja. A khmer építészetben egyáltalán nem szokványos épület párhuzamait látja Preah Vihearban, Phnom ChisorbanésBanteay Sreinél a Gopura IV-ben, míg Koh Ker esetén a Prasat G mellett felveti, hogy a Prasat Thom East Gopura IV esetén is hasonló funkcióval számolhatunk. Ea Darith a Raktár elnevezés mellett érvel, és a zarándokszállás funkciót valószínüsíti. Olivier Cunin, Ea Darith és Claude Jacques ezzel kapcsolatos útmutatásait ezúton is köszönöm. 
Ennek nyomai a nyugati oldalon nem látszanak, a keleti pedig egyszerü, közel négyzet alaprajzú épületként mutatkozik a felszínen. Ezért ezt az információt feltételesen kell kezelnünk. Ezek valószínűleg nem maradandó anyagból épült, mára már javarészt elpusztult épületek lehettek. Mindenesetre a pavilonépület, ami a Parmantier-féle alaprajzról hiányzik (!), egy a jelenleginél összetettebb szerkezetre enged következtetni. Az épületcsoport hiteles alaprajzának felderítése fontos része a további kutatásnak, amit azonban nehezít az, hogy a pavilon és a bejárat között ma az az út halad át, amelyen keresztül Koh Ker belső magterülete körbejárható. Erről a területről geofizikai vizsgálattal remélünk több információt szerezni, hogy a bejárati struktúráról és az épületek kapcsolatairól a jelenleginél sokkal pontosabb képet kaphassunk.

\section{A Prasat külső kerítőfala}

A Prasat külső kerítőfalának kutatására nyitott szondában, a külső oldalon, mintegy $80 \mathrm{~cm}$ mélységben sikerült elérnünk az altalajt. Az altalaj feletti, a kerítőfal-építéshez kapcsolódó rétegekben megfigyelt laterite-szemcsés építési törmelék arra utalt, hogy a nyugati elöépülethez hasonlóan a kerítőfal alapozásához is nagy mennyiségü építési törmeléket használtak fel, annak kialakítását egy nagyobb építkezés, feltehetően a Prasat belső épületcsoportjának építése előzhette meg. Így először szerezhettünk régészti bizonyítékot arra, hogy az épületcsoport építése belülről kifelé történt, a külső kerítőfal, illetve a pavilon csak egy későbbi fázisban épült meg. A külső építmények egy jelentősebb építkezéshez kapcsolódó nagyszabású tereprendezés után, részben annak építési törmelékét felhasználva jöttek létre (11. kép).

A szondákban megfigyelt rétegviszonyok alapján azonban nemcsak az épületek szerkezetére és az építési periódusokra vonatkozó információkat sikerült gyüjtenünk. Az alapkőzet, illetve az altalaj és a laterite-szemcsés, mesterséges szintek egymáshoz való viszonya alapján joggal feltételezhetjük, hogy a Prasat egy korábbi, természetes kiemelkedésen, kisebb dombon helyezkedett el. A központi szentélyt és a körülötte lévő épületeket itt építették fel, és ezek környezetét az építkezésekkel párhuzamosan, mesterségesen átalakították. 


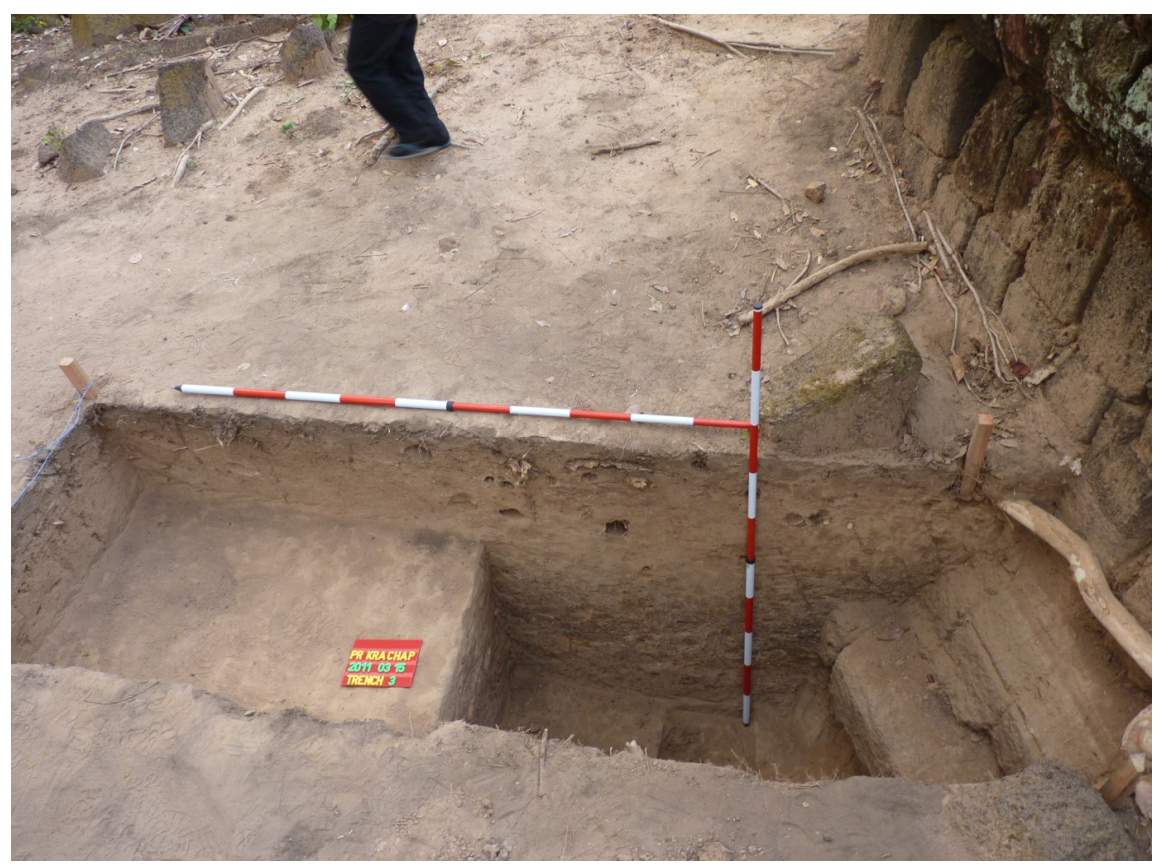

11. kép A külsö keritöfal lábazata az 1. szondában

A kerítőfal külső és belső oldala között jelentős szintkülönbség mutatkozott. A szondázás során kiderült, hogy a szentélyeket körülvevő fal és a kerítőfal közötti terület jelentősen fel van töltődve. Ez a feltöltés, amelyből jelentős mennyiségü tetőcserép és 11-13. századra keltezhető kerámia került elö, a belső oldalon elfedte az eredeti építési rétegekhez tartozó, durván profilált lábazatot. Az elfedésből, illetve föként a nagy mennyiségü tetőcserépből azt feltételezhetjük, hogy az épület történetében ebben az időszakban, illetve közvetlenül ezután változás történt. Mivel a területen későbbre datálható leletek nem kerültek elö, és egységes, az épületcsoport pusztulásával, illetve átalakításával kapcsolatos réteget nem sikerült azonosítani, felmerülhet akár az is, hogy az épület a 13. század után tulajdonképpen lakatlanná vált. 


\section{A Prasat Krachap belső magja és a külső kerítőfal közötti terület}

\section{(9. szonda)}

A Prasat nyugati galériájának déli homlokzata elött - a homlokzat és a kerítőfal közötti területet átvágva - egy közel 9 méter hosszú kutatóárkot nyitottunk. A szondázó kutatás célja a belső épületcsoport és kerítőfal építési fázisainak, a kettő egymáshoz való viszonyának vizsgálata volt. Bár a külső kerítőfal kutatása kapcsán már voltak információink a két fal közötti feltöltött terület belső rétegviszonyairól, ezt mindenképp szerettük volna kiegészíteni azzal, hogy megfigyeljük a két épített szerkezet kapcsolatát, és ezzel egy időben információkat gyűjtünk a belső rész építésének esetleges periódusairól (12. kép).

A nyugati galéria déli homlokzata előtti szakaszon még a kutatás megkezdése elött megtisztítottunk és kiemeltünk egy a homlokzatról már korábban lezuhant, ornamentálisan faragott, erősen megkopott homokkő csúcsdíszt (13. kép).

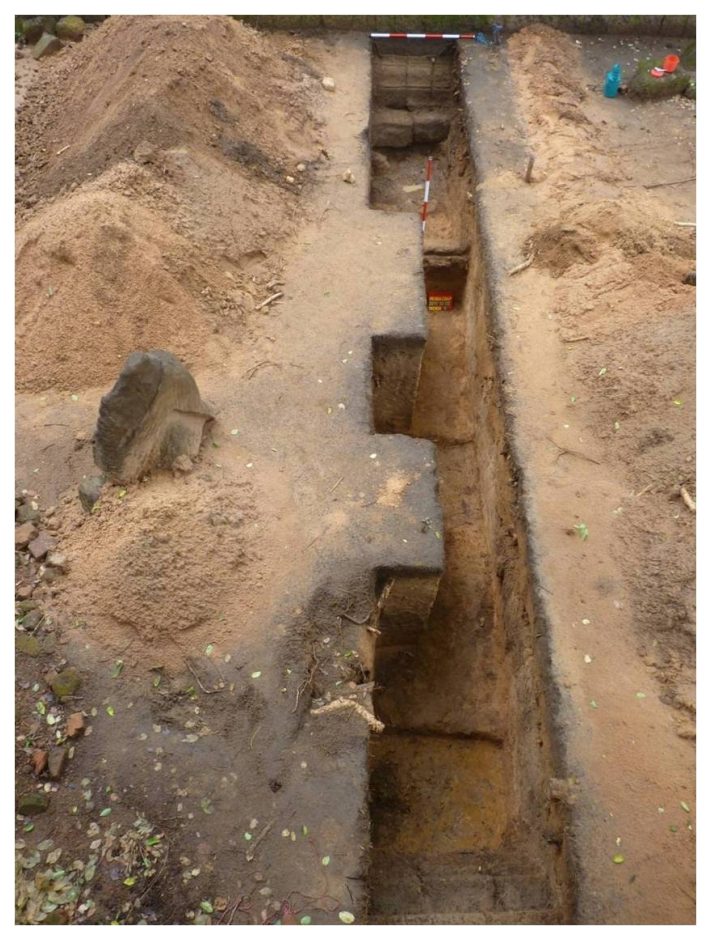

12. kép A keritöfalak között nyitott árok, 9. szonda (a szerzö felvétele) 


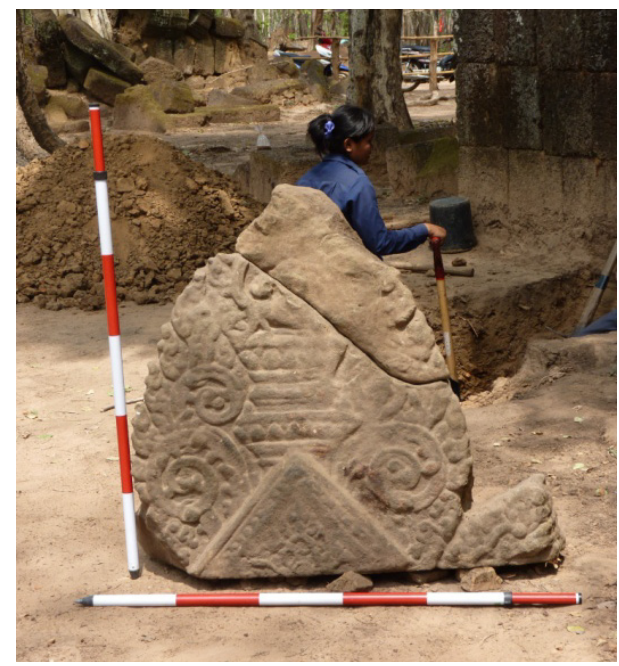

13. kép Homokkö csúcsdísz a kiemelés után (a szerzö felvétele)

Az említett terület feltárása során a korábbi szelvényhez hasonlóan itt is azt tapasztaltuk, hogy a Prasat és a kerítőfal eredeti, profilált lábazatait jelentős, $70 \mathrm{~cm}$ nagyságú feltöltés takarja. A szondában sikerült azonosítani az eredeti, feltehetően a 10. század első harmadára datálható építési réteget és a Parathoz tartozó járószinteket, jelenségeket.

A metszetek alapján az építés folyamata, az épület alapozási struktúrája jól azonosítható. A mintegy 1,5 méteres mélységben megtalált altalaj lejtése a két fal között nem számottevő ugyan, de a kerítőfal külső oldalán nyitott szondában tapasztalt jelentős eltérés és a terep szemmel látható esése azt a korábbi feltételezésünket igazolta, miszerint a Prasat egy a környezetéből kiemelkedő, kisebb, természetes dombon épült fel. A természetes kiemelkedésen laterite- és homokrétegekből alakították ki azt a felületet, amelyre a központi épületcsoport került. A galéria déli homlokzata elött sikerült megfigyelnünk a lábazathoz kapcsolódó építési szinteket is. A metszetben két oszlophelyet sikerült azonosítanunk. Mindkettő a homlokzat közelében található, amelyek az alapozáshoz használt homokrétegbe mélyedtek, de az építést követő járószintek elfedik őket. Feltehetően közvetlenül az építkezéssel hozhatók összefüggésbe, és joggal sejthetjük bennük az egykori építési állványzat maradványait.

Az építési szintet több járószint követi. A laterite-es, kemény, keskeny, letaposott rétegek az épületcsoport hosszú ideig tartó, folyamatos használa- 
tára utalnak. Erre a rétegsorra azután egy feltöltés került, ami a lábazat alsó, profilált rétegsorát elfedi. A feltöltődés homogén, nem hozható összefüggésbe eróziós jelenségekkel. Az ebből előkerült tetőcserép és 11-13. századra keltezhető kerámiatöredékek inkább azt látszanak megerősíteni, hogy ebben az időszakban az épület történetében jelentős változás történt, a galériák, illetve a belső épületek környezetében az eredeti járószint megemelkedett. A szint azonban nem a teljes lábazatot, hanem annak csak az alsó szakaszát takarja el, és ahhoz a nagyobb laterite tömbhöz húz, amely felett a lábazati profil újabb szakasza kezdődik. Ez a kutatás során meg is tévesztett minket, korábban ugyanis azt gondoltuk, hogy ez a tömb az alapozás része, de a bontás során kiderült, hogy annak csak egy eleméről van szó, és a faragott szakasz lefelé folytatódik.

Mivel a korábbival ellentétben ez a szint erősen lejt a külső kerítőfal felé, elképzelhető, hogy a feltöltésnek pusztán vízelvezetési szempontjai voltak, és a tetőkről lefolyó csapadékot kívánták a lábazatok felől ezzel a módszerrel elvezetni a kerítőfalak irányába, ahonnan feltehetően lefolyása lehetett az épületen kívüli területre. Mindenesetre az épületek változására, esetleges átalakítására utal az a homokkő faragványtöredék is, amelyet egy beásásban figyeltünk meg, és amelyre ez a bizonyos megemelt, a kerítőfalak felé lejtő járószint ráfed! Mivel ez a bizonyos beásás vágja a korai rétegeket, a faragvány földbe kerülése valószínüleg nem sokkal a járószint kialakítását megelőzően történt. Ennek az esetleges periódusváltásnak az igazolására azonban további nagyobb felületű feltárásra lesz szükség.

Az épületek folyamatos használatát jelző ezen rétegrend a külső kerítőfal belső oldalán nem mutatkozik. A járószintek nyomát itt nem találtuk, viszont jól látható a falak közét a későbbiekben kitöltő, markáns és tetőcserepekben gazdag, a leletanyag alapján a 11-13. századra keltezhető feltöltés. Ennek keletkezésével kapcsolatban egyelöre nincsenek ugyan egyéb információink, de a nagy mennyiségü tetőcserép az épület átalakítására, a tetők pusztulására, az épületcsoport ideiglenes vagy végleges elhagyására utal. ${ }^{8}$ Ez azonban egyelőre csak egy olyan munkahipotézis, amelynek alátámasztására, ezzel együtt a feltöltés és a járószint vizsgálatára további régészeti kutatásra lesz szükség.

$8 \quad$ A kronológiai megállapításainkat nagyban alátámasztotta, ugyanakkor a terület korai településtörténeti fázisaira is felhívta a figyelmet a Szegedi Tudományegyetem által végzet termolumineszcens kormeghatározás, erről lásd részletesen Sipos et al. 2013. 
A kutatás érdekessége, hogy a kutatóárokban kívül sikerült megfigyelnünk egy - az épülettel feltehetöen egykorú - kisebb laterite támfalat. Ennek funkciójával kapcsolatban valóban csak találgatásokba bocsátkozhatunk, de a metszet alapján könnyen elképzelhető, hogy ez a kisebb szerkezet az alapozáshoz használt homokréteg megtámasztására szolgált (14. kép).

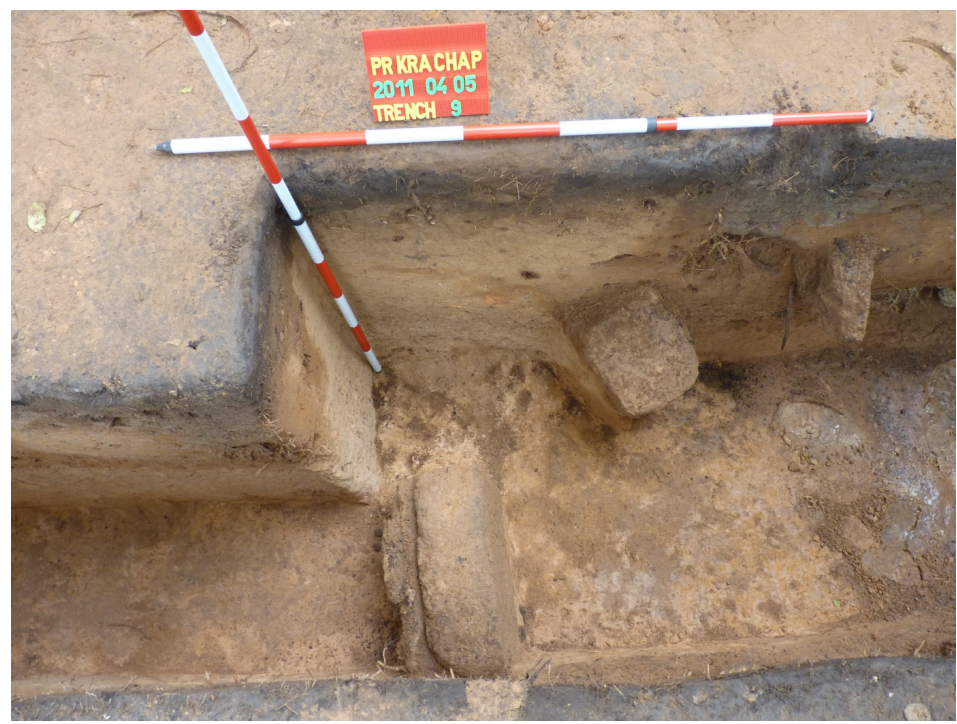

14. kép A szondában feltárt támfalszakasz (a szerzö felvétele)

\section{A Prasat északnyugati sarkán elhelyezkedő tó feletti, keletre húzódó magaslat}

Már a terepbejárás során szembetűnő volt a magaslaton talált leletek nagy száma és a reprezentatív leletanyag, a porcelán, illetve a mázas kerámia menynyisége. Ez és a felszínen szétszóródott laterite töredékek egy korábbi épületre, épületcsoportra utaltak.

A fedőréteg eltávolítása után kemény építésü, törmelékes kerámiában gazdag, tömörített réteget találtunk, amelyet az épületek alapozásánál használt és korábban már többször megfigyelt homogén homokréteg követett. Mindez igazolni látszik azt a feltételezést, mely szerint a nagyobb medence feletti magaslaton a Prasattal egykorú épület, épületek álltak, de ezek irányát, kiterjedését a szondában nem sikerült azonosítani. Feltehetően innen származik az 
az első hallásra talán kevésbé reprezentatív tárgy, ami a mindennapi élet igen fontos kelléke volt: egy háromágú, hordozható kerámiatűzhely töredéke. Ez alatt a kerámiaállvány alatt égett egykor a tủz, és erre helyezték az általában gömbös testü fözőedényeket (15-16. képek).

Három év szünet után, 2014 márciusában újabb három szondát nyitottunk a templom területén és a szentélykörzetet körítő kettős fal északi oldalán. ${ }^{9}$ A falszoros, illetve a falon kívüli terület kutatásának célja az volt, hogy - a déli oldalon korábban nyitott árokhoz hasonlóan - itt is megvizsgáljuk az épületcsoport építéstörténetéhez tartozó rétegeket, illetve az épület és a környezetében azonosított településrészletek kapcsolatát. Így tulajdonképpen egy teljes észak-déli keresztmetszetet kaphattunk a Prasat Krachap szentélykörzetét övező építményről. A templom építéstörténetére vonatkozó adatok mellett a romterület tervezett teljes feltárása miatt is fontos információkat reméltünk az újabb árkoktól, hiszen a kutatást követő helyreállítás során mindenképp igazodnunk kell az eredeti járószintekhez, amelyeket jelenleg jelentős földtömeg, illetve épülettörmelék fed.

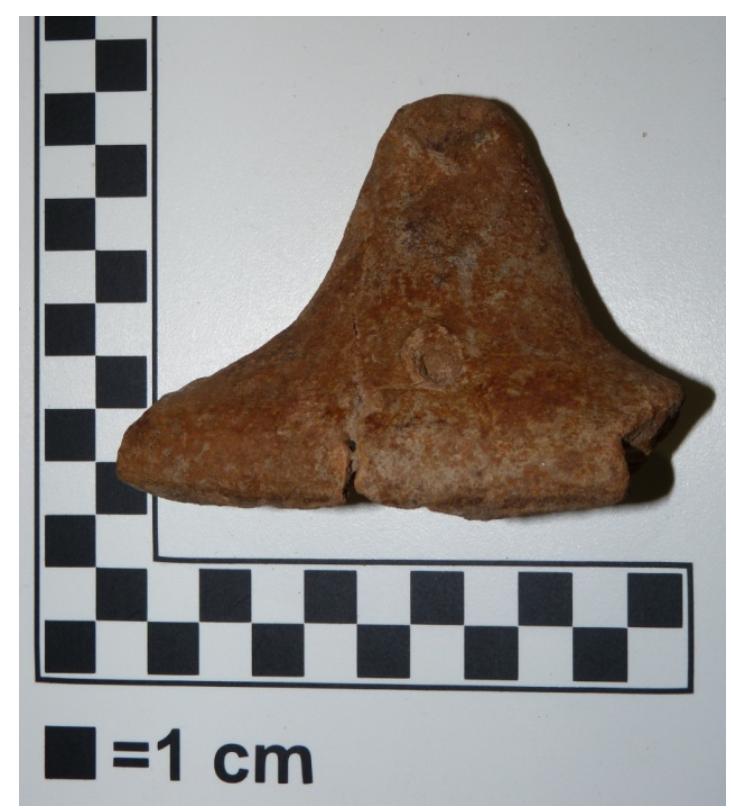

15. kép Kerámiatüzhely töredéke (a szerzö felvétele)

9 Belényesy 2015. 


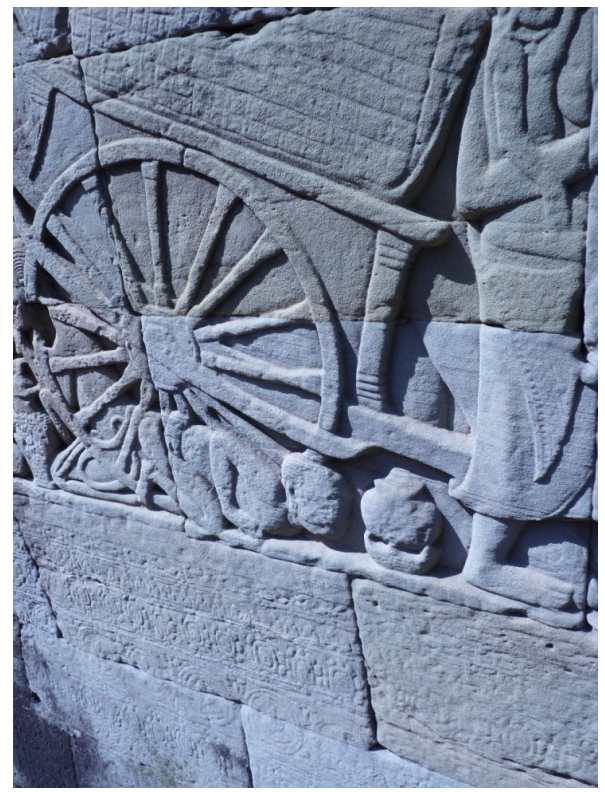

16. kép Kerámiatüzhely a bayoni relief egyik ábrázolásán (12-13. század fordulója), Angkor, Kambodzsa (a szerzö felvétele)

Ezek kezelése, deponálása, illetve a templom statikájának esetleges változása pedig jelentősen befolyásolhatják a régészeti feltárások és a müemléki helyreállítás megtervezését. Ez utóbbi szempontokat figyelembe véve eddigi ismereteinket mindenképp szerettük volna kiegészíteni a szentélykörzeten belüli adatokkal is.

A nagyobb kutatóárkot a laterite tömbökböl épített kettős körítő fal falszorosában nyitottuk, nagyjából az épületcsoport északnyugat-délkeleti középtengelyében (17. kép).

A feltárás során kiderült, hogy a profilált lábazatokhoz igazodó eredeti járószinteket mintegy 40-50 cm-es feltöltés fedte. Ez alatt mintegy 2 méter vastagságban sikerült ismét megfigyelnünk az építést megelözően kialakított mesterséges rétegrendet, a homok-, az agyagos kevert, erősen tömörített és a laterite-szemcsés rétegeket. A falszorosban a külső körítő faltól mintegy 2,5 méter távolságban, hasonlóan a nyugati galériasor déli homlokzata elött nyitott 9 szondához, itt is sikerült azonosítanunk egy kisméretü laterite blokkokból épített, a kötőfalakkal párhuzamos támfal maradványait. Az árok metszetében egyértelmüen látszik, hogy - az említett szondában megfigyeltekhez hasonlóan - ennek a laterite tömbökből rakott kősornak futnak neki a kül- 
ső körítő fal alapozásának rétegei, tehát szerkezetileg vélhetően összetartoznak. Ez a szerkezet egyben arra utal, hogy a külső körítő fal a már kialakított szentélykörzet és a belső laterite körítő fal után épült meg. A leletanyag zöme az egykori épületekből származó tetôcserép volt, amely nagy számban került elő a laterite tömbökből kialakított körítő falak alatti tömörített agyagos, laterite-szemcsés rétegből is. Az alapozási rétegekbe bekerülő építési törmelék, föként a tetőcserepek megjelenése egy korábbi településre, összefüggésben a laterite kősorral és a külső körítő fal alapozási rétegeivel, esetleg egy korábbi építési fázisra utalhatnak.

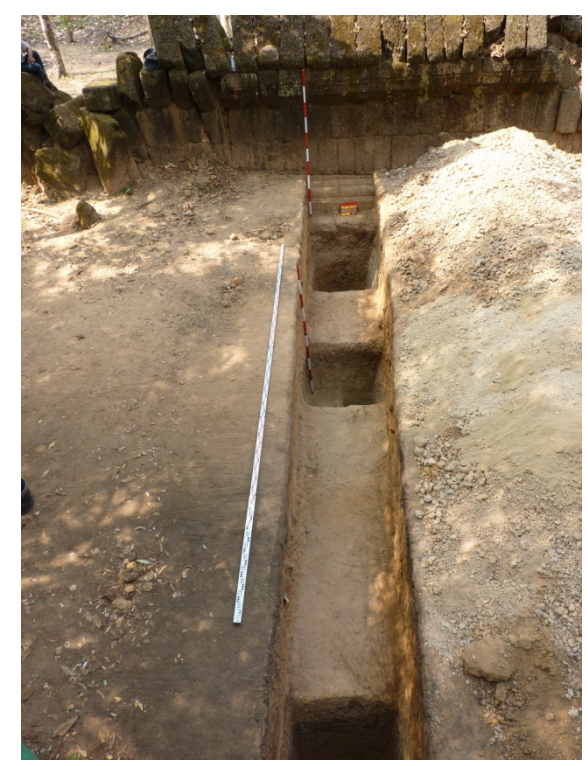

17. kép Kutatóárok az épületcsoport észak-délkeleti tengelyében (a szerzö felvétele)

Az árok meghosszabbításában nyitott szondában, a fal külső oldalán is azonosítani akartuk az építési rétegeket, amelyek rétegrendje a belső oldalon feltárttal tulajdonképpen megegyezett. Az egykori járószintet borító feltöltésből, illetve az ez alatti régekből nagy mennyiségben került elő a környező településre utaló háztartási kerámia leletanyag. A szonda végében, közel 6 méterre a külső körítő faltól - szerencsés módon - egy ép edényt is sikerült feltárnunk (18. kép). 


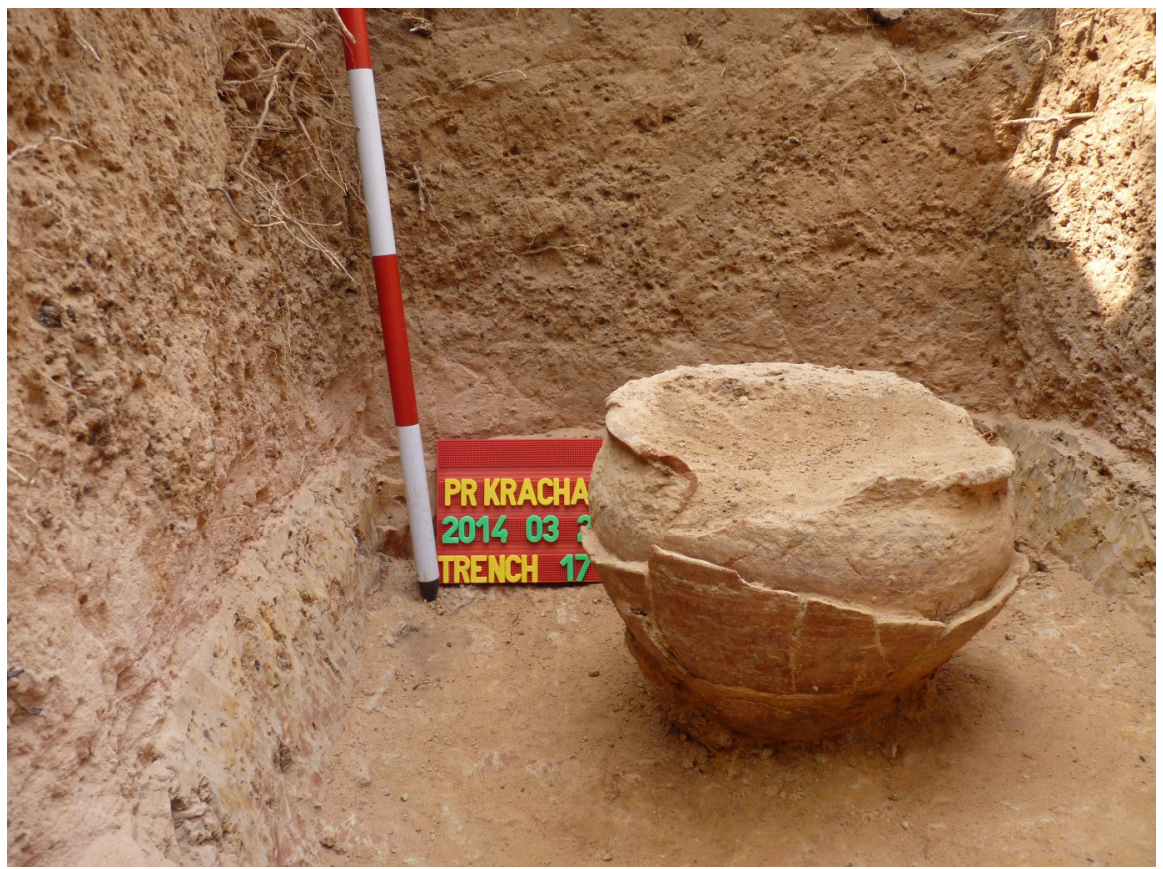

18. kép Ép edény a keritöfal külső oldalán (a szerzö felvétele)

Az edény a talaj nyomásától összeroskadt, fala megrepedt, ezért nem sikerült egészben kiemelnünk. Különlegessége, hogy tulajdonképpen az építést megelőzően kialakított, erösen ledöngölt agyagos és a lábazathoz csatlakozó laterite-szemcsés réteg határán in situ sikerült kibontanunk. Így kora feltehetően megegyezik a külső körítő fal építésével. Tekintettel arra, hogy vöröses színü, enyhén kihajló, egyszerü peremü, ívelt aljú, kézzel készített folyadéktartó edény volt, a 10-12. századig terjedő időszakon belüli keltezése nem finomítható. ${ }^{10}$

Az eredeti járószintek és a törmelékréteg vizsgálata miatt kisebb szondát nyitottunk a szentélykörzetben, a téglából épített központi szentély északi oldalán. Az 1×1,5 méteres kutatóárokban, az egységesnek tünő építési törmelékréteg alatt, a jelenlegi felszíntől mintegy 1-1,2 méter mélységben sikerült azonosítanunk az eredeti, homokkő lapokból kialakított járószintet (19. kép).

10 A meghatározásban nyújtott segítségéért külön köszönet illeti Dr. Ea Darith-ot. 


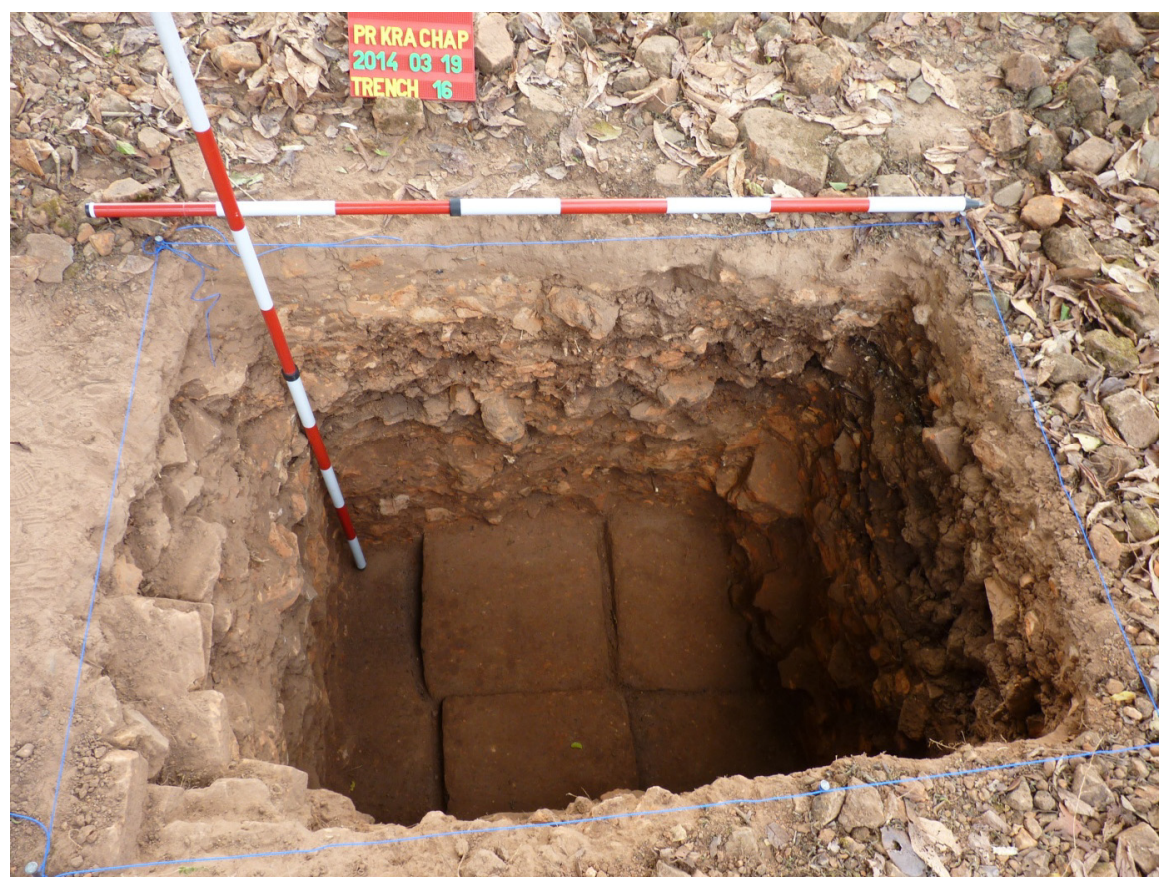

19. kép Homokkö járószint a központi szentély északi oldalán (a szerzö felvétele)

Az 50×50 centiméteres faragott kőlapokból kialakított padló abszolút magassága megegyezett a körítő falaknál azonosított lábazatok szintjeivel. A törmelékből csupán egy barna mázas edény kisebb oldaltöredéke és egy vörös színű mázatlan edény peremének maradványa került elő. Az eredeti járószint azonosításával szerzett információk rendkívül fontosak. A homokkő lapok jó állapota és a több mint egy méter vastag réteg arra enged következtetni, hogy a szentélykörzetet borító törmelék alatt feltehetően jó állapotban maradhattak fenn az eredeti lábazati szintek és járófelületek.

\section{Szemléletváltás, változások a kutatási stratégiában}

Ahogy erről a bevezetőben már szó esett, a terület kutatásának és inventarizációjának alapja a látható történeti emlékanyagon, tehát az épületeken és az egyedi mütárgyakon (csatornák, gátak, Rahal) alapult. A felderítés és azonosítás előrehaladása után merülhetett fel először a terület belső összefüggéseinek, kronológiájának kutatása. Ez sajátos módon egy kérdésre, kérdés- 
csoportra épült fel. A kutatás kiindulópontja ugyanis nem volt más, mint a IV. Jayavarman uralkodása alatt kiépülő királyi központ karakterének, épített környezetének meghatározása, különös tekintettel a reprezentatív helyszínekre, így a királyi rezidenciára és a központi szentély környezetére, illetve az origónak tekintett 928-as évszámra.

Míg a történeti, epigráfiai és művészettörténeti kutatás alapvetően ezt a kérdést és a belső kronológiát próbálta tisztázni, Koh Ker „,várossá” való kiépülése, a települési környezet változása is vonzó kutatási céllá vált, különös tekintettel a komplex vízgazdálkodási rendszer egyes elemeire. ${ }^{11}$

Koh Ker-i kutatásunk elején azért döntöttünk egy mintaterület kiválasztása mellett, mert a jellemzően nagyobb területekre koncentráló, topográfiai jellegü kutatás mellett szerettük volna konkrét régészeti adatokkal kiegészíteni a jellemzően a földfelszínen is érzékelhető jelenségekből származó információkat. A régészeti feltárással egy területre koncentráltunk, és komplex régészeti programot indítottunk a Prasat Krachap környezetében (a választás egyértelmü volt, hiszen az épület gazdag epigráfiai forrásanyaggal rendelkezik, és építészettörténeti szempontból feltehetően Koh Ker 10. századi kiépülésének idején emelték, mérete technikai szempontból is kezelhetővé teszi). Az viszont már a kutatás elején világossá vált, hogy az egyes épületcsoportok nem izolált egységek, hanem egy feltehetöen gazdag, de ismeretlen településhálózat csomópontjai.

A nagyszámú epigráfiai forrás a kevés történeti vonatkozás mellett ugyanis kiterjedt ellátó bázisra, szolgáltató jellegü településekre utalt. Nem épületet kerestünk tehát, hanem egy gazdasági és spirituális központot és annak közvetlen ellátó rendszerét. Szerettük volna megtalálni a feliratokon megjelenő, a templomnak szolgáló személyek falvait és feltérképezni ennek az ellátó rendszernek a jellemzőit. Annak ellenére, hogy az intenzív földmüvelés hiányában nem számítottunk sok leletre, az eredmények alaposan megcáfolták korábbi feltevéseinket.

A 2011-es terepbejárás során a Prasat Krachap közvetlen környezetében ugyanis intenzív lakóövezetek nyomait láttuk, és a templomhoz köthető leletanyag mellett a felszíni leletgyüjtés egyértelmúen falusias környezetre utalt. Ráadásul a kijelölt közvetlen környezet határán a leletek intenzitása nem szünt meg. Úgy tünt, hogy a különbözö templomok között érintetlennek tủnő erdő valójában intenzív történeti lakóövezet lehetett. Szerencsés

11 Evans 2013. 
módon a Koh Ker-i munkánk kezdete egybeesett egy nagyszerű módszertani változással, amely alapvetően megváltoztatta a településtörténeti, régészeti kutatással kapcsolatos feltevéseinket. Az azóta kiindulópontként használt LiDAR ${ }^{12}$ felvételezés ugyanis egyértelmü áttörést hozott a kevésbé érzékelhető antropogén változások vizsgálatában. Ezt a fordulópontot akár egy új időszámítás kezdetének is tekinthetjük. Az új szemléletü felmérési módszer ugyanis igazolta korábbi elképzeléseinket, és az addigi dzsungel és a templomok közvetlen környezete egyértelmüen történeti lakóövezetté változott. Óriási mennyiségü adat került a birtokunkba, amelyeknek értelmezése ma is folyik. ${ }^{13}$

\section{Hogyan érintette mindez a Prasat Krachap környezetében végzett kutatásunkat?}

A képek feldolgozása során egyértelmüen azonosíthatóak voltak azok az egyedi struktúrák, amelyek a korábbi, részben az épületcsoportokhoz kapcsolódó, a falakhoz igazodó, nem maradandó anyagból épült településekre, történeti úthálózatra és az egykori tervezett vízgazdálkodásra utalnak. Ebböl a szempontból óriási jelentősége van az egyedi, sokszor inzuláris jellegű formák, az egyes épületek, telkek vagy a telkekhez kapcsolódó víztározók azonosításának, amelyeket a régészeti kutatással is össze tudunk kapcsolni. Hiszen ennek a távérzékelési eljárásokkal azonosított történeti településrétegnek a közvetlen régészeti bizonyítéka a Prasat Krachap külső kerítőfalán

12 A LiDAR (Light Detection and Ranging) tulajdonképpen egy lézer alapú távérzékelési rendszer, amely lehetőséget teremt a talaj felszínén található elváltozások vizsgálatára. A pontsürüségből adódóan nem csupán az elváltozások mérésére, de egyes zavaró tényezők, így például a vegetáció szürésére is alkalmas. Így különösen az erdős, kevésbé bejárható területeken mutatkoznak meg a gyorsaságból, a pontosságból és szürésből eredő előnyei. Az első khmer kulturális örökség feltérképezését célzó (azóta is folyamatos) programban (Khmer Archaeological Lidar Consortium) Koh Ker is szerepelt. Ez óriási lehetőséget adott a korábban kevésbé érzékelhető finomabb elváltozások meghatározásánál. Az elemzett és több rendszerszerű szüréssel vizsgált ún. pontfelhő állományok alapján elöállított képek döntően befolyásolták korábbi kutatási stratégiáinkat (Evans 2013: 95-97).

13 Ennek kapcsán ki kell emelnem, hogy kutatócsoportunk (Kuszinger Róbert) olyan eljárást dolgozott ki, amely a LiDAR képek értelmezési lehetőségeit kitágította, és ezzel újabb lehetőség nyílt egyes tendenciák, rendszerek alaposabb megfigyelésére, lásd Kuszinger 2015. 
kívüli terület gazdag, egykori intenzív életre utaló leletanyaga. Itt a régészeti lelet nem csupán visszaigazolása az egykori megtelepedésnek, hanem egyértelmü kronológiai támpontot nyújt a - térben és kapcsolatrendszereiben jól azonosítható - antropogén környezet értelmezéséhez (20. kép).

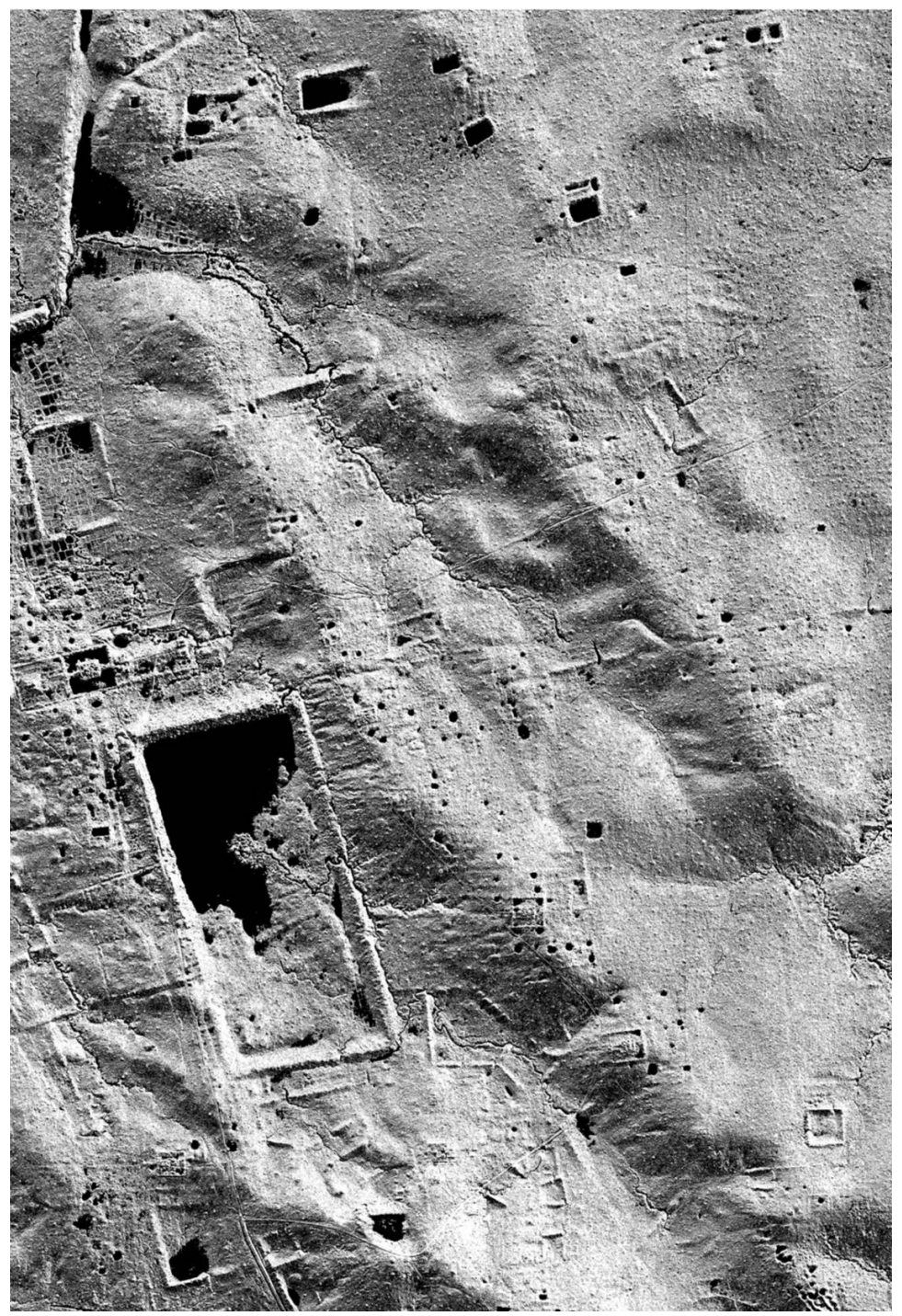

20. kép Koh Ker LiDAR mérésen alapuló domborzati modellje (felvétel: KALC, feldolgozás: Kuszinger Róbert) 
A fenti gondolatmenetet folytatva egyértelműnek tünik a következtetés, hogy azok az anomáliák, amelyek alapján az egyes településrétegek közötti eltérésekre következtethetünk, talán kronológiai eltérésekre utalnak, és ezekben több építési periódus vagy éppen egyes településrészek felhagyása sejthető. Erre egyelöre nincsenek régészeti bizonyítékaink, de a Prasat Krachap környezetében azonosítható, a települések változására utaló jellegzetes formák miatt a kutatást ezekre a területekre is kiterjesztettük. Ezért a rendelkezésre álló adatok birtokában a templom kelet-nyugati tengelyén áthaladó lineáris út(?)szerkezet került a figyelmünk középpontjába (21. kép).

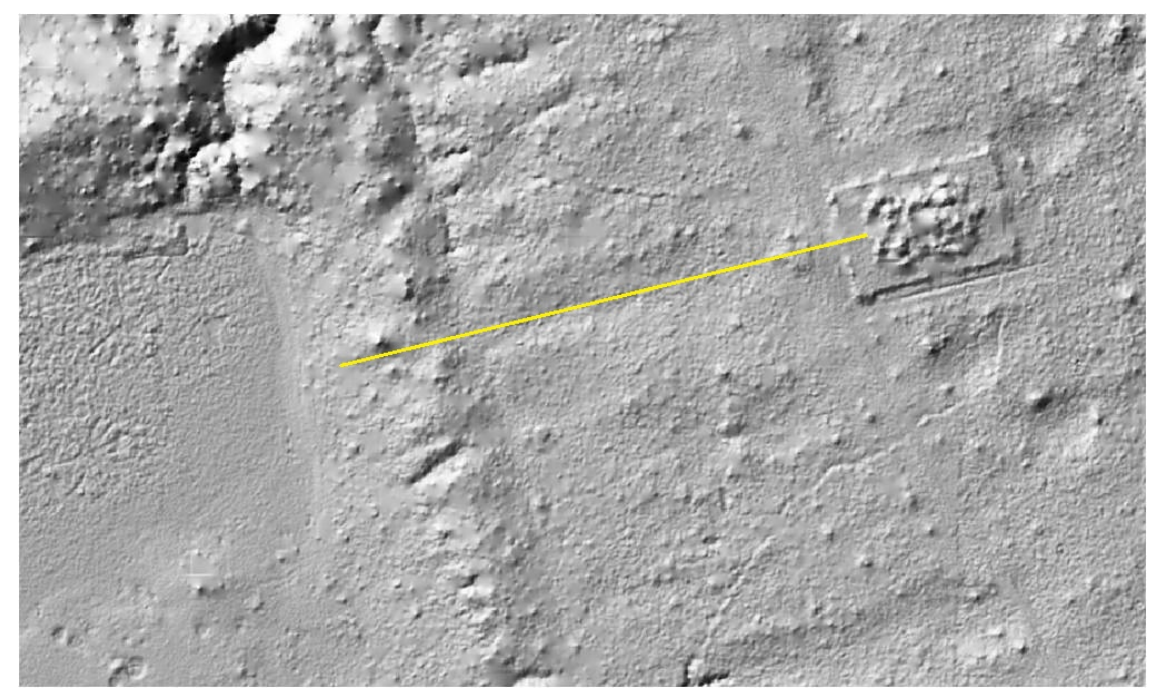

21. kép Feltételezett út a Prasat Krachap LiDAR alapú domborzati modelljén (felvétel: KALC, feldolgozás: Kuszinger Róbert)

A felvételek alapján ugyanis úgy tủnik, hogy ez a fö irány meghatározó lehet a Prasat Krachap környezetében található egykori települések szempontjából, és egyértelmüen összeköti a templomot a központi víztározóval, Rahallal. Ennek a kelet-nyugati lineáris rendszernek az antropogén jellege, kiépítettsége a LiDAR képeken is szembetünő volt. 2011-ben sikerült feltárnunk egy, a templom keletre néző kapujával szemközti épületet, valamint ennek tengelyében egy pavilon és egyben a Rahal felé mutató lépcső maradványait. Ezért a víztározó és a Prasat Krachap között egy korábbi, reprezentatív kapcsolatot feltételeztünk, amelynek azonosítását már 2014 júniusában megkezdtük. Bár a vegetációs időszak nem kedvezett a terepbejárásnak, a 
Prasat Krachap és a Rahal közötti erdőben sikerült azonosítanunk egy laterite tömbökkel szegélyezett, 180 méter hosszú és közel 5 méter széles reprezentatív út maradványait. A nagyméretü laterite tömbök némelyikén faoszlopoknak kialakított, faragott mélyedéseket azonosítottunk. Az út és a Rahal nyugati partfalának találkozásánál a terep kialakítása egy épített teraszra utalt, amelynek közelében egy homokköből faragott oroszlán maradványait is megtaláltuk (22. kép).

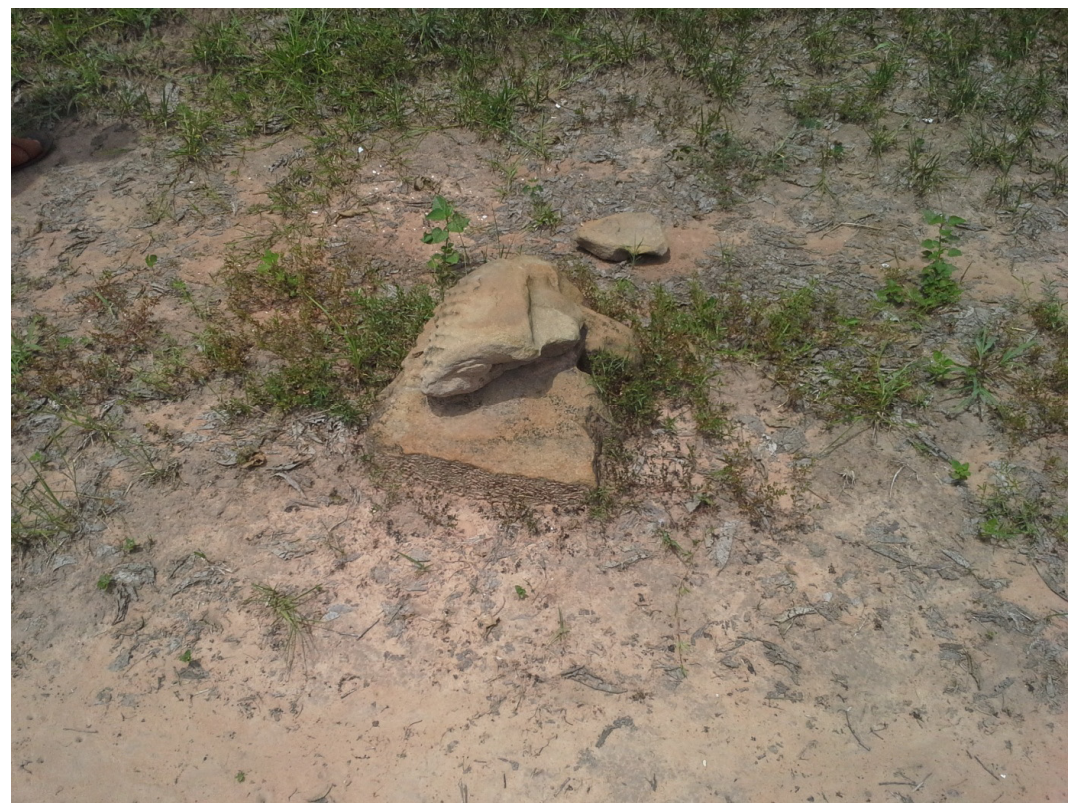

22. kép Homokkö oroszlánfej a feltételezett terasz közelében (a szerzö felvétele)

A terepbejárás során az út vonalán kívül igyekeztünk minden antropogén beavatkozásra utaló nyomot megvizsgálni. Ennek eredményeként a templom közelében, kissé távolabb az út tengelyétől, egy homokkő felszínen néhány, kőfejtésre utaló nyomot fedeztünk fel (23. kép).

Ezek után 2015 márciusában újabb négy szondát nyitottunk, immár azzal a szándékkal, hogy a 2014-ben a LiDAR feldolgozás segítségével azonosított útszerkezet egyes részleteit vizsgáljuk, illetve információkat szerezzünk a kőfejtés felszíni nyomaival kapcsolatban. ${ }^{14}$

14 Belényesy 2015. 


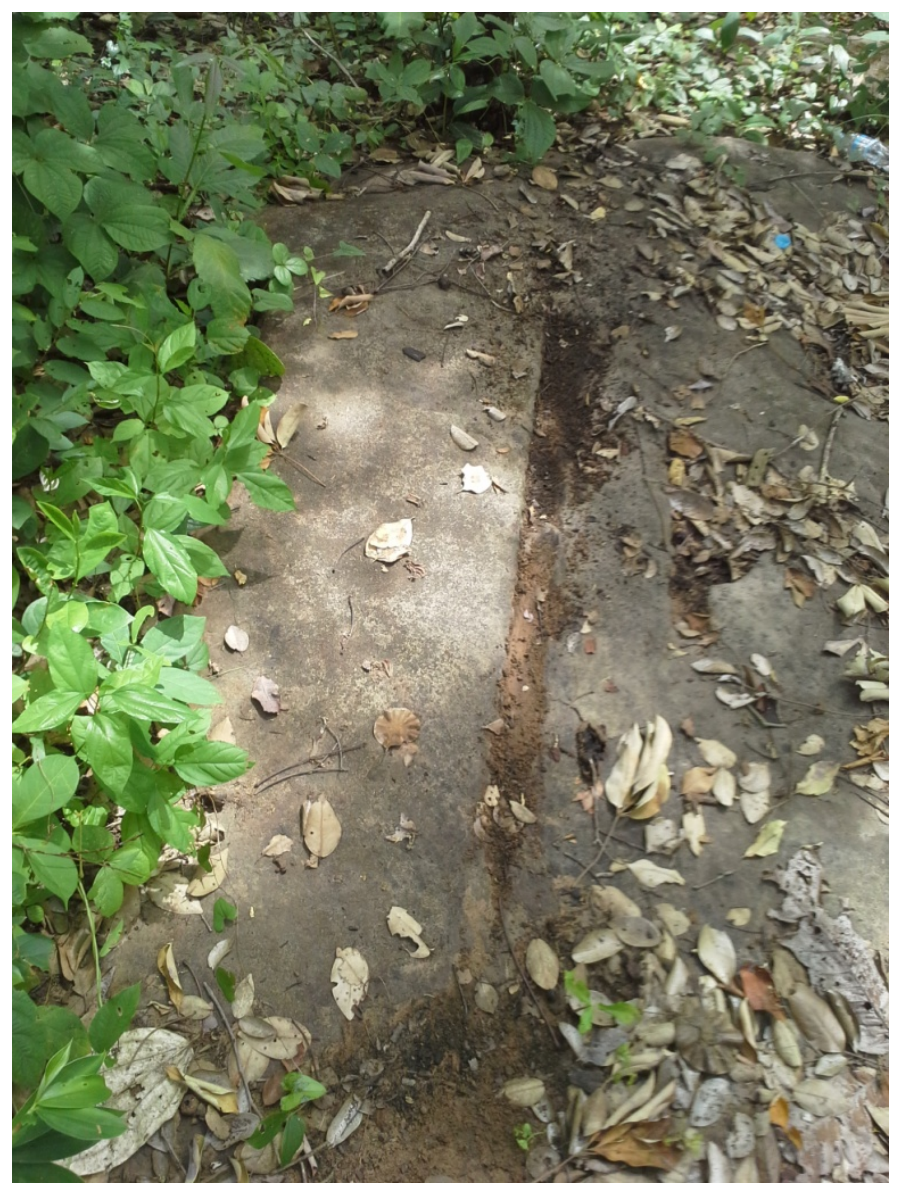

23. kép Egykori köfejtés nyomai a felszinen a Prasat Krachap közelében (a szerzö felvétele)

Ahogy arról már többször szó esett, az azonosított út a Prasat Krachap kelet-nyugati fötengelyéhez igazodott, és az erdőben egyértelmủen azonosítottuk az egykori szerkezet elemeit. Elöször az út vonalában teljesen megtisztítottuk a területet, és eltávolítottuk az aljnövényzetet. A szondák kijelölésénél igyekeztünk az értelmezés szempontjából fontos területekre koncentrálni, így elsősorban a Prasat Krachap keleti kapuja előtt feltárt épület lépcsőjére mint kiindulási pontra, illetve a Rahal és az út csatlakozásánál feltételezett teraszra mint keleti végpontra. Ezen kívül szondát nyitottunk a korábban megfigyelt oszlophelyek faragásait mutató útszegély vizsgálata céljából (20. szonda). 


\section{Az út}

A szondát a 2011-ben feltárt lépcsőtől keletre, nagyjából a lépcső és az útszerkezet feltételezett csatlakozásánál nyitottuk, ahol a felszínen egy homokkő oroszlán kisebb töredékei mutatkoztak. Az árok északi oldalán, a felszín alatt mintegy $20 \mathrm{~cm}$ mélységben megtaláltuk az útszegély eredeti helyükböl kimozdult laterite tömbjeit. A déli oldalon az oroszlán felszíni töredékeinek dokumentálása után tovább mélyítve az árkot, az eredetileg feltehetően a lépcsőt díszítő homokkő oroszlán testének nagyobb, egyben fennmaradt töredékét sikerült kibontanunk és a bontás után kiemelnünk. Az oroszlán töredékei ugyan másodlagos helyzetben kerültek elő, ugyanakkor feltételezhetően eredeti pozíciójukhoz közel. A test töredékét tulajdonképpen az eredeti járószinten találtuk meg. Itt egy kisebb felületen sikerült az út eredeti burkolatát is kibontanunk. Eszerint a homok-, agyag- és laterite-szemcsés rétegekkel alapozott, délfelé enyhén leejtő, mintegy 4,8 méter széles utat szabálytalan homokkő lapokkal burkolták. Ez visszaigazolta korábbi feltételezéseinket az úttal kapcsolatban, hiszen az erdőben folytatott terepbejárás során, ahol a kidőlt fák az út eredeti szerkezetét is megbolygatták, több, szabálytalan homokkő laptöredéket találtunk, amelyet feltételesen az eredeti burkolathoz kötöttünk, de először az itt feltárt. szondában sikerült egyértelmü bizonyítékot találnunk az eredeti rétegekről és az „in situ” járószintről (24. kép).

A Rahal felé lejtő út középső szakaszán, a feltételezett fa felmenő szerkezet és az útrétegek vizsgálata miatt nyitott szondában tulajdonképpen a korábbihoz hasonló rétegrendet sikerült megfigyelnünk, azzal a különbséggel, hogy az út e szakaszán az eredeti járószint tulajdonképpen a felszínen található. Az eróziónak, illetve egyéb külső hatásoknak erősen kitett területen a korábban megfigyelt homokkő burkolatnak csak elenyésző nyomai mutatkoztak, az szinte teljesen eltünt. Ehhez hasonlóan a laterite tömbökön azonosítható oszlophelyek ellenére nem találtuk nyomát az egykori felmenő szerkezeteknek. Azok meglétéről és a feltehetően faoszlopokon nyugvó tető eredeti fedéséről csak az út külső oldalán előkerült nagyszámú tetőcserép tanúskodott. A kőtömbökbe faragott körvonalak alapján az oszlopközök (oszloptengelyek között mérve) 1,7 méter szélesek lehettek. 


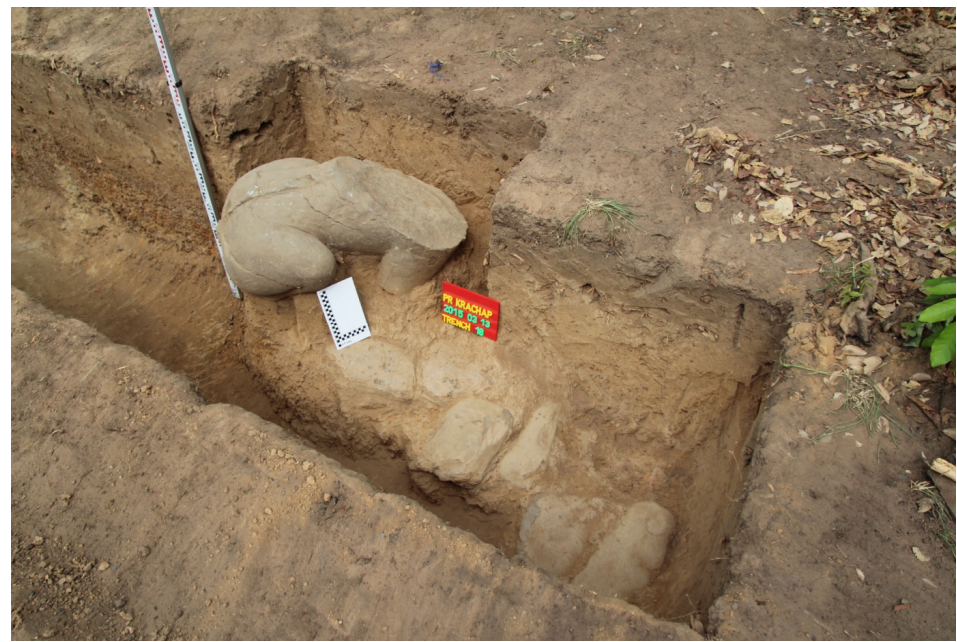

24. kép Homokkö oroszlán teste és az egykori, homokkö lapokkal boritott út maradványai (a szerzö felvétele)

\section{Terasz a Rahal partján}

A 2014-ben történt bejárás során a Rahal keleti partfala és az út keresztezödésénél egy terasz tömbjét azonosítottuk. Az aljnövényzet tisztítása után ezt a feltételezést nem tudtuk érdemben vizsgálni, hiszen a feltételezett terasz területét szinte teljesen benőtte az erdő, így az érdemi vizsgálathoz nagyobb fák kivágására is szükség lenne. Ugyanakkor a terasztól a Rahal irányában lévő partfal tisztítása során sikerült felfedeznünk az eredeti, épített kő szerkezetet, amely nyilvánvalóan összefüggésben van az úttal és a korábban említett terasszal. Itt már az aljnövényzet eltávolítása után világosan kivehető volt egy, az út tengelyéhez igazodó, kisméretü, $30 \times 15$ centiméteres alapterületü laterite tömbökből rakott lépcső „,in situ” maradványa, amelyet északi oldalán jóval nagyobb, faragott laterite tömbökből rakott szegély kísért. Ugyanez a szegély a déli oldalon az itt álló fák miatt sérült volt, de a lépcső közel 8 méteres szélessége így is azonosítható volt. A kevés talajréteg alatt, tulajdonképpen jó állapotban fennmaradt, feltehetően a teraszt és a Rahal egykori medrét összekötő lépcső szegélyének északi oldalán a szabálytalan, kisebb-nagyobb laterite és homokkő tömbökből kialakított eredeti partfal kisebb szakaszát is sikerült feltárnunk (25. kép). 


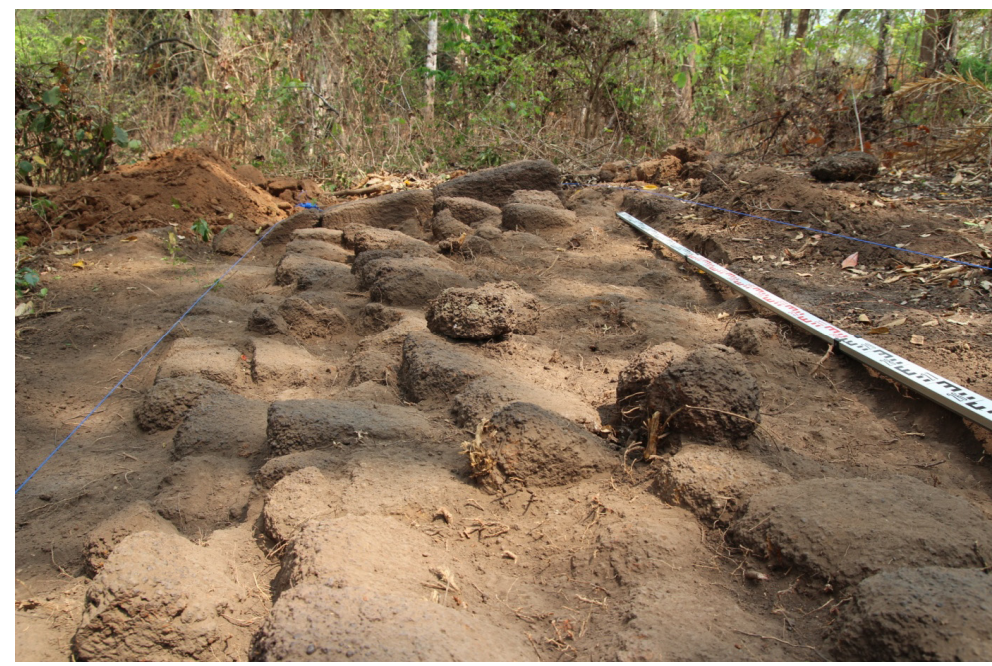

25. kép A Rahal irányába futó egykori lépcsö (a szerző felvétele)

\section{Köfejtö}

A 2014-ben a Prasat Krachaptól alig 40 méterre felfedezett kőfejtési nyomok környezetének régészeti kutatása az azonosítás óta szerepelt terveink között. A terület szondázásával elsősorban a helyi kőbányászat bizonyítékait kerestük. A természetes homokkő felszínt, ahol a kőfejtés jeleit láttuk, megtisztítottuk, és ezek dokumentálása után a mesterségesen megmunkált felszín déli oldalát $5 \times 2,5$ méteres felületen kibontottuk. Ennek során az eredeti homokkő felszínen 4 db 50×150 centiméteres alapterületü kőlap kivágásának, illetve további kettő hasonló méretü kivágásra való előkészítésének nyomait azonosítottuk. A körbevágott tömbök körül a kivájt homokkőben sikerült megfigyelnünk a bányászásnál használt fém fejtöszerszámok által hagyott nyomokat is. Az itt folyt feltárás során az is bizonyossá vált, hogy ezt a kőbányát a kifejtés után felhagyták, és szisztematikusan visszatemették. A kőbe mélyített vájatok ugyanis ugyanazzal a laterite-szemcsés, részben tetőcserép-töredékekkel kevert réteggel voltak visszatemetve, amelyeket az út feltárása során, illetve az épületek alapozási rétegeinek vizsgálatakor már többször azonosítottunk. A gondosan elplanírozott és keményen ledöngölt rétegek arra utalnak, hogy a helyszínen feltehetően a Prasat Krachap építéséhez kapcsolódó kőfejtés okozta tájsebet az építkezés befejeztével vél- 
hetőleg egy nagyobb területre kiterjedő tereprendezés részeként szisztematikusan tüntették el. Így joggal feltételezhetjük, hogy a templom építése során az eredeti természeti környezet adottságainak tudatos kihasználása mellett annak átalakításával is számolnunk kell. Azaz elképzelhető az eredeti természetes táj radikális átformálása, amely a Prasat Krachapon túl más templomok környezetével kapcsolatban is felmerülhet (26. kép).

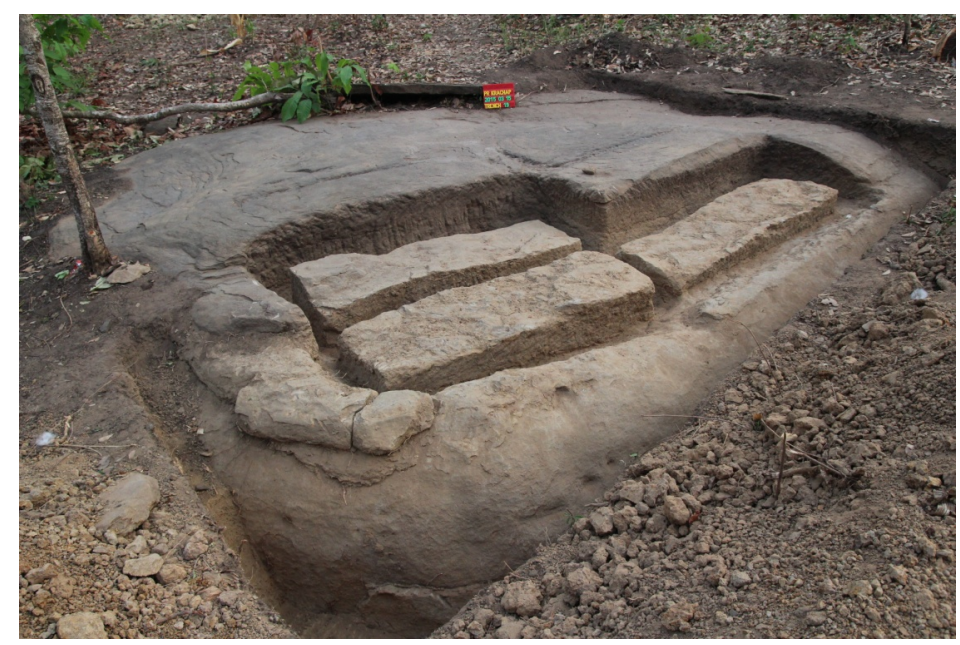

26. kép A Prasat Krachap közelében feltárt köfejtő

\section{Összefoglalás}

A 2011 óta folyamatos kutatás általános tanulsága, hogy a Koh Kerről alkotott képet és kutatási stratégiákat milyen módon alakították át a modern távérzékelési eredmények, és mindezzel együtt hogyan alakult át a kutatás általános szemlélete, illetve hogyan fordult Koh Ker eddig ismeretlen településtörténete felé. Az eddigi eredmények és a jövőbeni kutatások egyértelmü kiindulópontjává vált a LiDAR adatok ismerete és használata. Mindezzel együtt Koh Ker településtörténeti képe és az értelmezés lehetőségei is kitágultak, így az egykori jelentős települést ma egyre inkább egy sajátos településhálózatként kell elképzelnünk. A kutatás korábban ennek a hálózatnak fő részleteire, az egyes templomokra és a szemmel látható jelenségekre koncentrált, de kitöltetlen maradtak a hálózat fő csomópontjai közötti területek. A kapcsolatok (utak, vízrendszer) és a templomokat körülvevő struktúrák (mint 
a települések vagy ipari tevékenység) intenzív rendszere, ezek összefüggései nem voltak ismertek. Pedig ezeknek a részleteknek nagy jelentőségük van a terület (Koh Ker) létrejötte és funkciójának megértése szempontjából. Talán pontosabban tudjuk megrajzolni és értelmezni a természeti környezet átalakításának mértékét és jellegét, a terület betelepülésének és benépesülésének folyamatát. Ebben a munkában a távérzékelés és a régészeti feltárás kéz a kézben jár. Így nincs szó arról, hogy hagyományos feltárási módszereinkkel fel kell hagynunk, hiszen jelenlegi elképzeléseink kronológiai támpontjait az epigráfiai adatok mellett a leletektől remélhetjük. Mindemellett a természettudományos vizsgálatok, a kis beavatkozással járó szisztematikus mintavételezés mellett a nagy felületü szisztematikus feltárások rejtik a legnagyobb lehetőséget a felszín alatti Koh Ker megismeréséhez.

\section{Másodlagos szakirodalom}

Belényesy, Károly 2013. „Report on Archaeological Research Work in the Precinct of Prasat Karchap at Koh Ker.” In: Renner, Zsuzsanna (ed.) Archaeological Mission at Koh Ker, 2011. Budapest: Publications of the Hungarian Southeast Asian Research Institute [3], 19-24.

Belényesy, Károly 2015. „Archeological Investigations in Koh Ker, Prasat Krachap Temple and Surroundings, 2014-2015." In: Kuszinger, Róbert (ed.) Koh Ker Project. Annual Report 2015. Budapest: Hungarian Southeast Asian Research Institute, 8-35.

Belényesy, Károly - Ea, Darith 2011. „Preliminary Report on the Archaeological Survey at Koh Ker, Prasat Kracap.” In: Kuszinger, Róbert (ed.) Koh Ker Projekt, Interim report for ICC TC 2011. Budapest: HUNINCOR, 5-16.

Evans, Damian 2010-2011 [2013]. „The archaeological landscape of Koh Ker, Northwest Cambodia." Bulletin de l'École française d'Extrême-Orient 97/98: 91-150.

Jacques, Claude 2011. „The Prasat Krachap.” In: Kuszinger, Róbert (ed.) Koh Ker Projekt, Interim report for ICC TC 2011. Budapest: HUNINCOR, 3-4.

Kuszinger, Róbert 2015. „Lidar Data Application at Koh Ker.” In: Kuszinger, Róbert (ed.) Koh Ker Project. Annual Report 2015. Budapest: Hungarian Southeast Asian Research Institute, 81-106.

Parmentier, Henri 1939. L'art khmèr classique: Monuments du quadrant Nord-Est. Paris: Les Éditions d'Art et d'Histoire.

Sipos, György - Tóth, Orsolya - Belényesy, Károly - Bozsó, György 2013. „Thermoluminescence Dating of Pottery Fragments from Koh Ker, Cambodia.” In: Renner, Zsuzsanna (ed.) Archaeological Mission at Koh Ker, 2011. Budapest: Publications of the Hungarian Southeast Asian Research Institute [3], 72-86.

Wickery, Michael 2001-2002. History of Cambodia. Summary of Lectures Given at the Faculty of Archaeology. Phnom Penh: Royal University of Fine Arts. 